\title{
Research Paper \\ Effectiveness of Compassion-focused Therapy on Self-esteem, Empathy, and Forgiveness in Child Labor
}

\begin{abstract}
Masoumeh Hosseinverdi ${ }^{1}$, Zahra Pourassadi ${ }^{2}$, Somayeh Keshavarz ${ }^{* 3}$, Alireza Kakavand ${ }^{4}$
1. M.A. in Psychology, Department of Psychology, Faculty of Social Sciences, Imam Khomeini International University, Qazvin, Iran 2. M.A. in Psychology, Department of Psychology, University of Science and Culture, Tehran, Iran

3. Assistant Professor, Department of Psychology, Faculty of Social Sciences, Imam Khomeini International University, Qazvin, Iran 4. Associated Professor, Department of Psychology, Faculty of Social Sciences, Imam Khomeini International University, Qazvin, Iran
\end{abstract}

Citation: Hosseinverdi M, Pourassadi Z, Keshavarz S, Kakavand A. Effectiveness of compassion-focused therapy on self-esteem, empathy, and forgiveness in child labor. J Child Ment Health. 2021; 7(4): 181196.

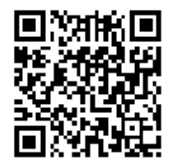

URL: http://childmentalhealth.ir/article-1-1064-en.html

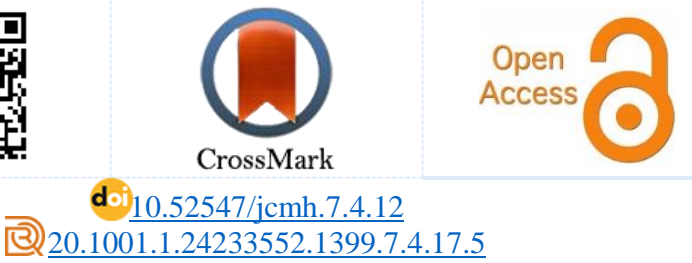

A R T I C L E I N F O

\section{Keywords:}

Compassion-focused

therapy,

self-esteem,

empathy,

forgiveness,

child labour

\section{A B S T R A C T}

Background and Purpose: Child labour refers to the exploitation of children through any form of work that deprives them of their childhood, and threatens their mental, physical, and educational health. The present study aimed to investigate the effectiveness of compassion-focused therapy on self-esteem, empathy, and forgiveness in child labour.

Method: This research was a quasi-experimental study with pretest-posttest control group design. The population of the present study consisted of all 10 to 14 years old girls engaged in child labor in Tehran in 2019. The research sample consisted of 24 girls who were selected through convenience sampling, based on the inclusion criteria. The instruments used included Coopersmith's Self Esteem Inventory (1967), Forgiveness Questionnaire (Rye et al., 2001) and Interpersonal Reactivity Index (Davis, 1983). Initially, all children were pre-tested. Then, the experimental group received eight 60min sessions of compassion-focused therapy (Gilbert, 2009), while the control group underwent no intervention. Finally, the post-test was conducted on both groups. Data were analyzed by covariance analysis in SPSS19.

Results: Statistical findings indicated significant differences between experimental and the control group in terms of self-esteem $(F=47.69 ، \mathrm{P} \leq 0.001)$. Also, the results showed that the mean difference of empathy and forgiveness variables between the experimental and control groups was not statistically significant.

Conclusion: Considering that self-esteem has widespread effects on children's success in many areas, including the quality of interpersonal relations, education, and adaptation, it can be concluded that in affected children who have a lot of shame and self-criticism, compassion-focused therapy increases the self-esteem, by modifying and enhancing their interpersonal interactions.
Received: 31 Aug 2020

Accepted: 11 Dec 2020

Available: 18 Mar 2021

* Corresponding author: Somayeh Keshavarz, Assistant Professor, Department of Psychology, Faculty of Social Sciences, Imam Khomeini International University, Qazvin, Iran.

E-mail: S.keshavarz@soc.ikiu.ac.ir

Tel: (+98) 2833901648

2476-5740/ (C) 2021 The Authors. This is an open access article under the CC BY-NC-ND license

(https://creativecommons.org/licenses/by-nc-nd/4.0/). 


\section{Extended Abstract}

\section{Introduction}

Child labour can be defined as the production of economic goods and services by children less than 18 that can deprive them of their childhood and is harmful for their physical and mental development (1). In addition, many of these children are at risk for serious dangers, including being used for drug trafficking. $(\varepsilon)$

One of the psychological problems of child labour is low level of self-esteem in these children. Selfesteem is an important factor in the mental health of children and supports them in stressful situations. Self-esteem indicates the amount of confidence in one's worth or abilities. Children with low level of self-esteem have poorer mental health (e.g. high anxiety and drug abuse) and may suffer from a sense of emptiness and isolation $(5,6,7,8)$. In contrast, high self-esteem protects the person from negative experiences such as social exclusion.( $\left.{ }^{9}\right)$

In addition, the level of empathy and forgiveness which are among the factors influencing relationships is low in child labour $(11,13)$. Empathy can be defined as the ability to understand the feelings of another and it consisted of the affective and cognitive components. The cognitive dimension is related to understanding the feelings of another, while the affective dimension involves sharing the emotional reactions of another one (11). Great deal of research has examined interventions that attempt to increase self-esteem, empathy and forgiveness $(5,6,11,13)$. Self-compassion is one of the interventions helping people to feel safe and to connect with their negative aspects without being engaged in exaggerated self-criticism $(21,26)$. Therefore, present study aimed to investigate the effectiveness of compassion-focused therapy on self-esteem, empathy and forgiveness in female child labor.

\section{Method}

This research was a quasi-experimental study with pretest-posttest control group design. The study population consisted of all 10-14 year-old female child labour studying at Sobhe Royesh Institute in Tehran in 2019. The research sample consisted of 24 girls engaged in child labour, selected through convenience sampling based on the inclusion criteria. The instruments used in this study included Coopersmith's Self Esteem Inventory (34), Forgiveness Questionnaire (36) and Interpersonal Reactivity Index (38). Initially, all participants were pre-tested. Then, the experimental group received eight 60-min sessions of compassion-focused therapy developed by Gilbert (26), while the control group underwent no intervention. Finally, both groups underwent the posttest. Data were analyzed by covariance analysis in SPSS19.

\section{Results}

Table 1 reports the descriptive statistics, including the mean, standard deviation, kurtosis, and skewness for both groups at the pre-test and post-test phases.

Table 1: Descriptive statistics related to empathy, forgiveness and self-esteem

\begin{tabular}{|c|c|c|c|c|c|c|c|}
\hline \multirow{2}{*}{ component } & \multirow{2}{*}{ group } & \multirow{2}{*}{$\begin{array}{c}\text { Pre-test } \\
\text { Mean } \\
\end{array}$} & \multicolumn{3}{|c|}{ Post-test } & \multirow{2}{*}{ Skewness } & \multirow{2}{*}{ kurtosis } \\
\hline & & & Standard deviation & mean & Standard deviation & & \\
\hline \multirow[t]{2}{*}{ empathy } & experiment & 17.33 & 11.75 & 27.01 & 9.19 & 0.128 & 0.148 \\
\hline & control & 15.08 & 12.59 & 25.25 & 12.65 & 0.198 & 0.201 \\
\hline \multirow[t]{2}{*}{ forgiveness } & experiment & 21.01 & 10.79 & 26.01 & 6.19 & 0.221 & 0.128 \\
\hline & control & 20.41 & 10.77 & 23.71 & 10.71 & 0.278 & 0.325 \\
\hline \multirow[t]{2}{*}{ Self-esteem } & experiment & 20.12 & 3.75 & 26.16 & 2.65 & 0.192 & 0.143 \\
\hline & control & 13.7 & 3.51 & 14.16 & 3.41 & 0.245 & 0.158 \\
\hline
\end{tabular}

As it can be seen in table 1, the self-compassion training increased the post-test mean score of empathy, forgiveness, and self-esteem in the experimental group compared to the control group. Although the changes were not significant for empathy and forgiveness, significant change was observed in self-esteem. To compare the effectiveness of self-compassion on empathy, forgiveness, and selfesteem, one-way ANCOVA was used. Initially, the assumptions for ANCOVA, including normality and homogeneity of variance were examined at the significance level of 0.05 . 
Table 2: Results of ANCOVA for comparing the scores of empathy, forgiveness and self-esteem in the experimental and control groups

\begin{tabular}{ccccccccc}
\hline component & Source of changes & SS & df & MS & F & P & Eta & Statistical power \\
\hline \multirow{4}{*}{ empathy } & Pre-test & 16725.33 & 1 & 16725.33 & 59.85 & .001 & 0.615 \\
& group & 588 & 1 & 588 & 2.10 & 0.15 & 0.009 \\
forgiveness & error & 5868.66 & 21 & & & & \\
& Pre-test & 33867.18 & 1 & 33867.18 & 185.77 & 0.001 & 0.550 \\
& group & 180.18 & 1 & 180.18 & 0.94 & 0.33 & 0.018 \\
Self-esteem & error & 4011.12 & 21 & & & & 0.996 \\
& Pre-test & 16502.08 & 1 & 16502.08 & 738.34 & 0.001 & 0.489 \\
& group & 1017.52 & 1 & 1017.52 & 45.69 & 0.001 & 0.248 \\
& error & 469.39 & 21 & & & & 0.998 \\
\end{tabular}

As shown in table 2, results of ANCOVA indicate that there was a significant difference between the experimental and control groups in terms of selfesteem at the posttest phase $(\mathrm{P}>0.01)$. Therefore, it can be concluded that self-compassion training significantly increased the self-esteem in the children. The effect size implied that $25 \%$ of the changes in self-esteem can be explained by selfcompassion training. Results also indicated that there was no significant difference between the groups in terms of the mean difference of empathy and forgiveness.

\section{Conclusion}

The present study aimed to investigate the effectiveness of compassion-focused therapy on selfesteem, empathy, and forgiveness in female child labour. The results showed that this intervention increases the self-esteem in these girls. The findings of this study on self-esteem increase coincide with some previous research $(5,6,7,8,9)$. In this regard, the individuals who grow up in traumatic environments, generally have difficulty in being gentle and kind to themselves or others and thus interpret the behavior of others negatively, however; the use of selfcompassion exercises calms the mind, reduces stress and increases self-esteem in children (26).

Also, results of this study showed changes in the empathy and forgiveness of the experimental group; however, these changes were not significant compared to the control group. These findings are in contrast with previous research $(11,21)$ which showed significant effect of compassion-focused therapy on empathy and forgiveness. There is at least one explanation for this contradiction. The participants of the present study were female children, while the previous research collected data from other participants. An underlying cultural difference in gender dynamics, empathy, or forgiveness could account for the conflicting results. Because of their position, the girls involved in child labor tend to magnitude the mistakes of others, which in turn can reduce the empathy and forgiveness in them. Therefore, according to these results, it is suggested that the effect of cultural context and gender be considered in therapeutic and psychological interventions.

\section{Ethical Considerations}

Compliance with ethical guidelines: This study was conducted independently. The permission for conducting it on the participants was issued by the Sobhe Royesh Institute in Tehran, bearing letter number 417/69/1972 dated 01.11.2019 and the principle of gaining the informed consent of the participants was observed.

Funding: This study was conducted without any financial support.

Authors' contribution: The first author was the producer of the training package and helped in conducting the research, the second author was the instructor of the training sessions, the third author was the corresponding author who supervised this research, and the fourth author analyzed the data obtained.

Conflict of interest: There is no conflict of interest in this study.

Acknowledgments: We would like to appreciate the participants, administrative staff and teachers of Sobhe Royesh School. 


\section{اثربخشى شفتدرمانى بر حرمتخود، همدلى، و بخش كود كان كار}

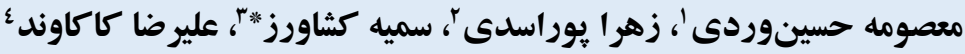

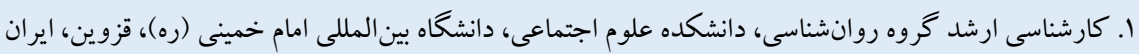

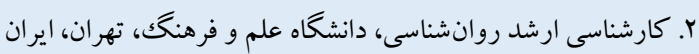

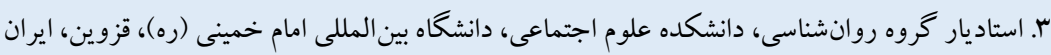

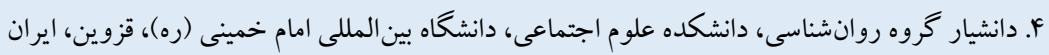

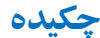

زمينه و هدف: كود كان كار به فعاليتهايى مشغول هستند كه با سن آنها تناسب ندارند، به همين دليل از تجربه دوران كودكى بى بهره

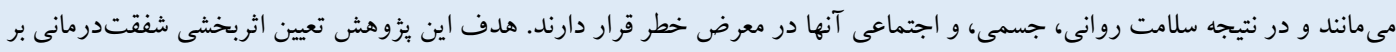
حرمت خود ، همدلى، و بخشش در كود كان كار است.

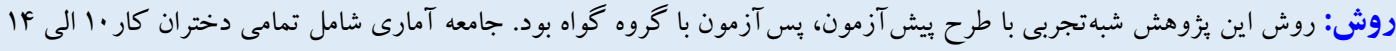

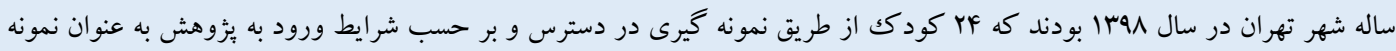
مورد مطالعه انتخاب شدند. ابزار مورد استفاده شامل يرسشنامه حرمت خود كويراسميت (199V)، مقياس بخشايش گرى ردى رى و همكاران

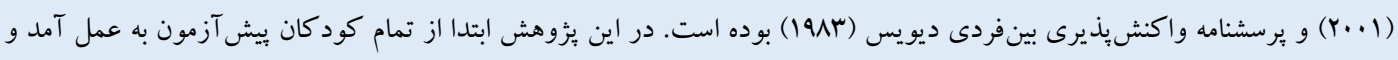

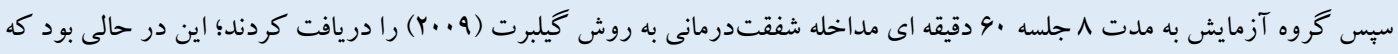

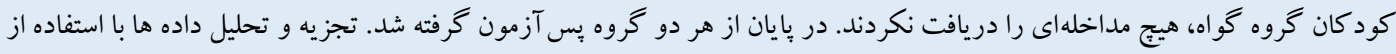
تحليل كوواريانس و با ويرايش 19 نرم افزار Spss انجام شد.

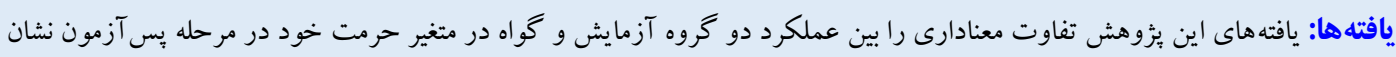

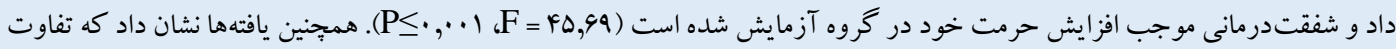

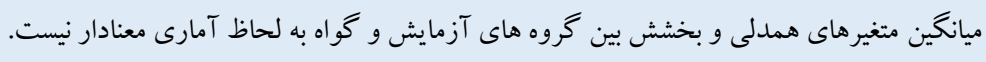

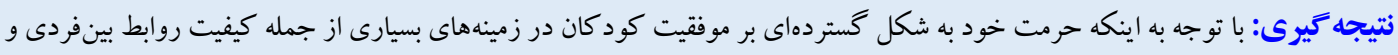

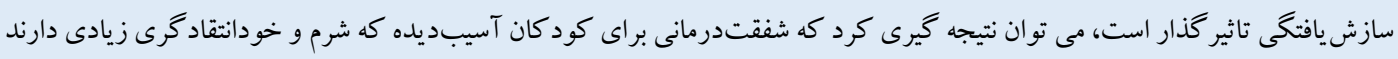
با اصلاح و افزايش تعامل هاى بين فردى باعث افزايش حرمت خود مى شود.
مشخصات مقاله

كليدوازهها:

شفقتدرمانى،

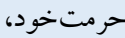

همدلى،

بخشش،

كودك كار

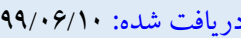

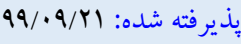

منتشر شده:

* نويسنده مسئول: سميه كشاورز، استاديار گروه روانشناسى، دانشكده علوم اجتماعى، دانشگاه بين المللى امام خمينى (ره)، قزوين، ايران.

رايانامه: S.keshavarz@soc.ikiu.ac.ir

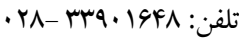


شايستخى، و احساس كناه و شرم نسبت به خود دارند و از دوست نداشتن

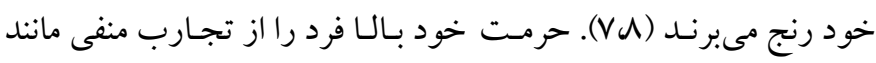

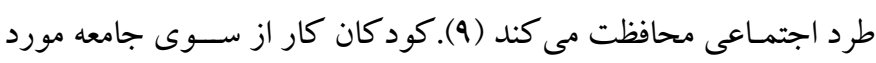

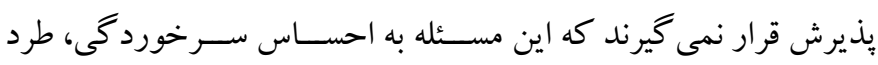

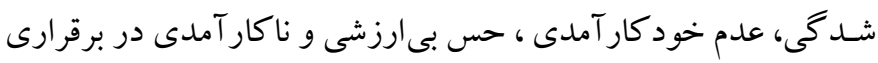
ارتباط مؤثر در اين كود كان منجر مىشود ( • (1)

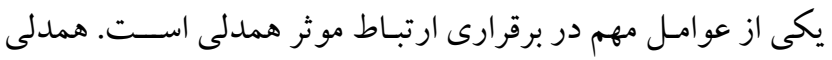

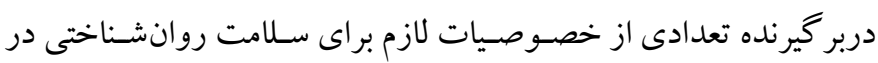

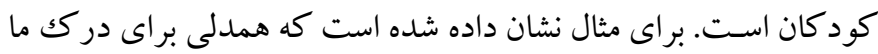

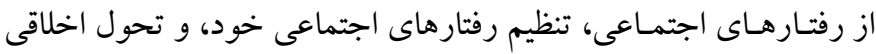
ضـرورى اسـت؛ بنابر اين تحول هملى در كود كان مانع ايجاد بسيارى از

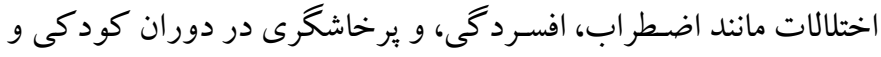

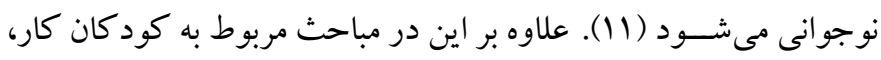

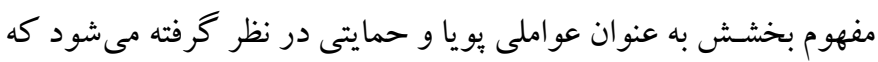
كود كان كار را در جهت سازش يافتكى با شرايط نامطلوب يارئ يارى مى بـدهد.

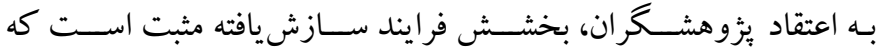
نشـاندهنده رهاسـازى احساس ها، شناختها، و رفتار هاى تنفر آميز نسبت

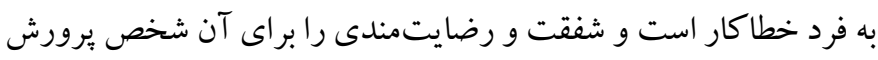

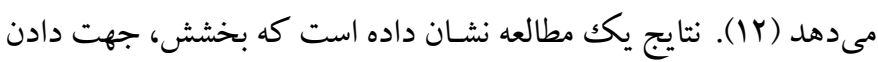

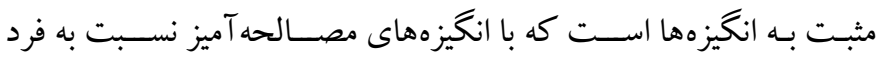

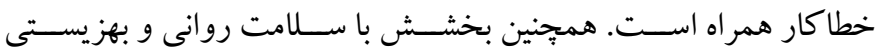

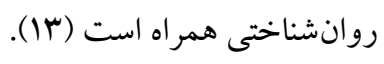

بنابراين براى كاهش بيامدهاى منفى و آسـيبـهايى كه كود كان كار

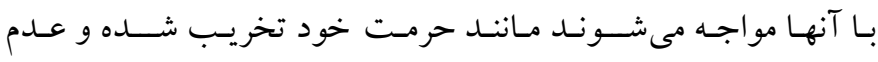

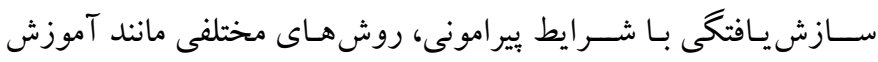

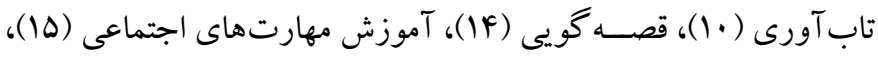

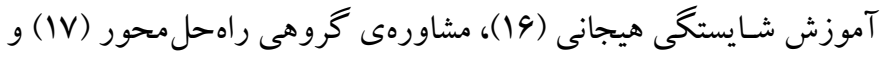

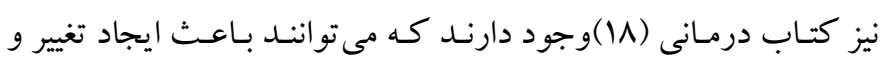

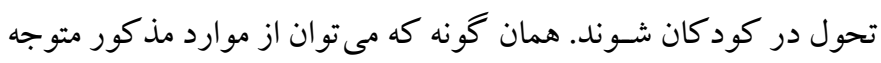

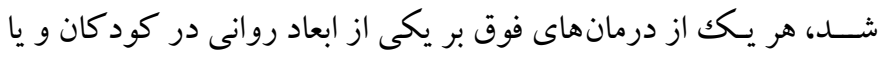

3. Self esteem
مقدمه

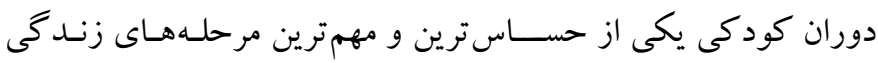

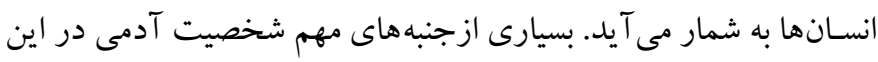

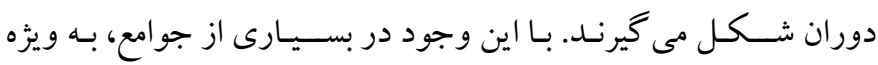

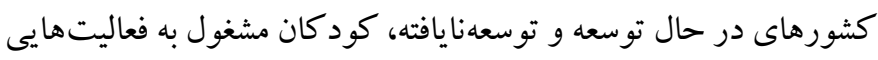

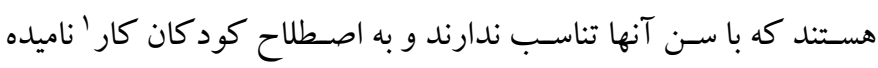

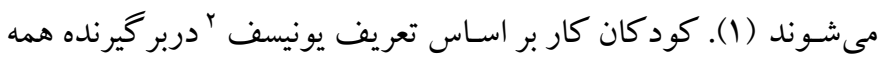

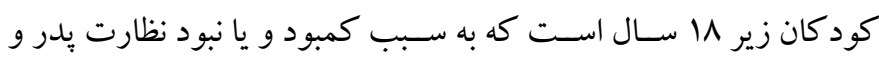

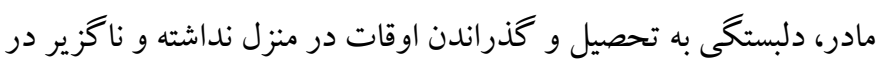

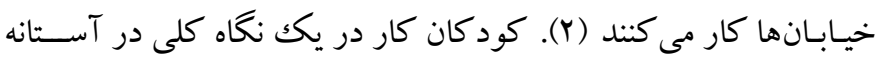
آسـيب بذيرى و رفتارهاى ضــــاجتماعى قرار دارند، بنابر اين نه تنها كار

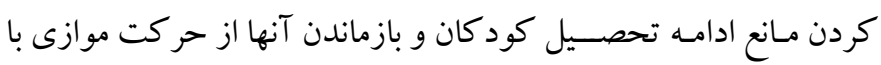

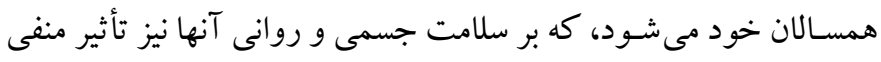

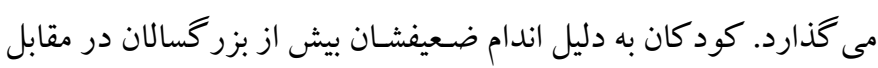

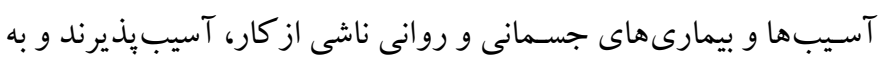

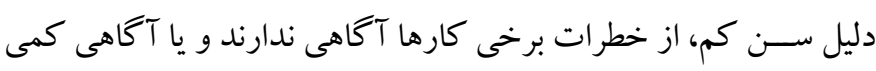

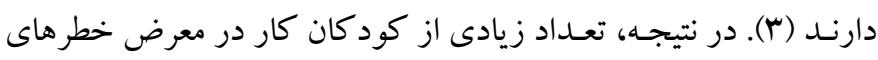

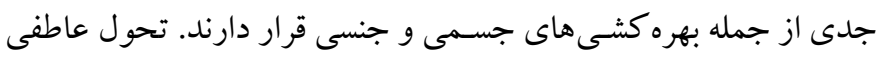

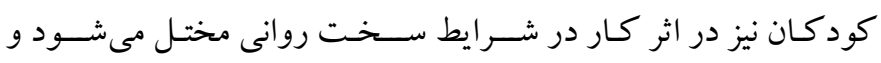

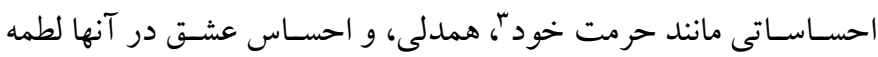

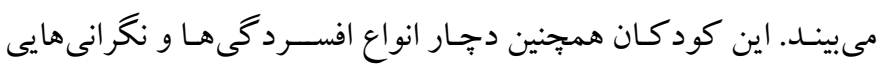
مىشوند كه با سن آنها تناسبى ندارد (F). يكى از عو امل روانشـناختى موثر بر سازش يافتكى با محيط بير امون،

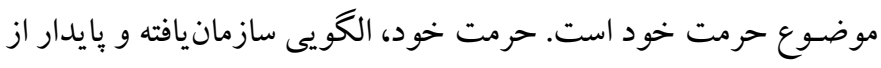
ادراكات فرد را بيان مى كند كه با تجربه فرد و تفسير ديخران از آن آن تجربه

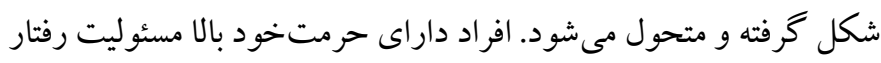

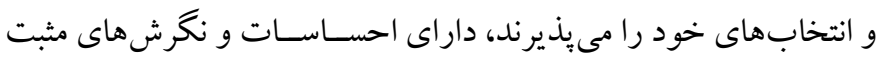

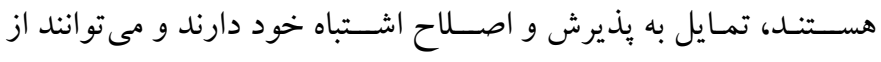

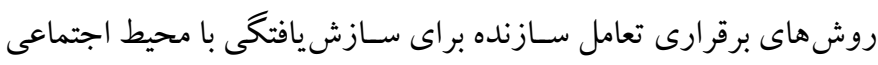

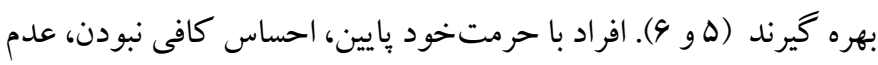

1. Labour children

2. Unicef 
به بخشـايش ديخران براى خطاهايشان مر تبط باشد (99). همرجنين از آنجا

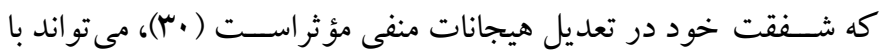

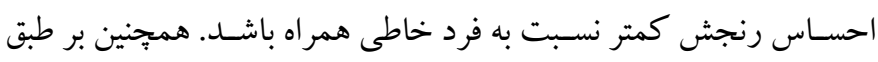

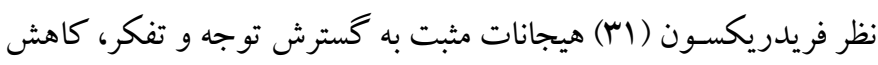

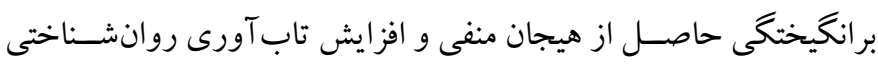
منجر مىشـود و اين امكان وجود دارد كه شفقت خود از طريق هيجانات

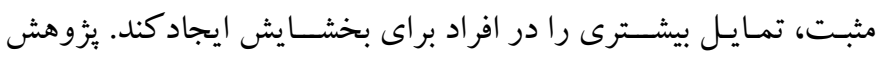

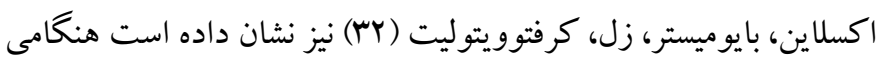

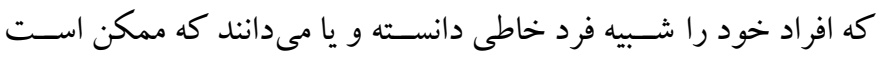
خودشـان نيز همان خطا را داشـته باشــند، فرد خطاكار را بيشتر مى بخشند.

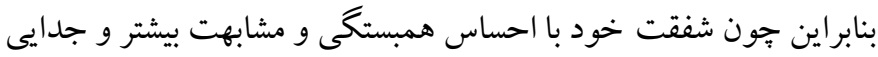

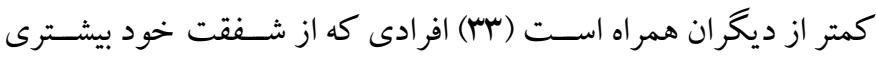
برخوردارند، ميل بيشترى نيز به بخشايش ديخران نشان مىدهند.

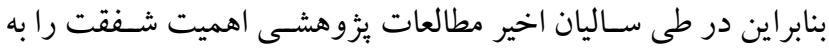

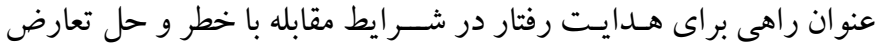

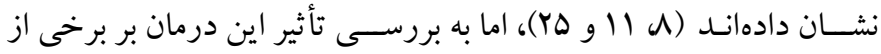

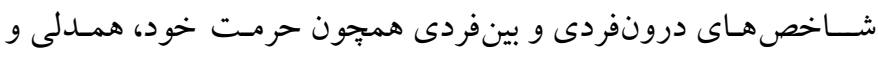

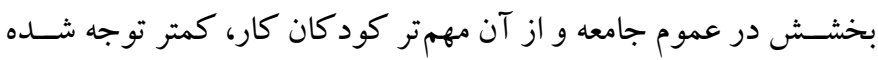

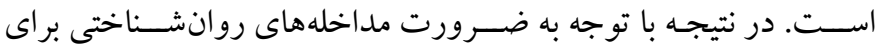

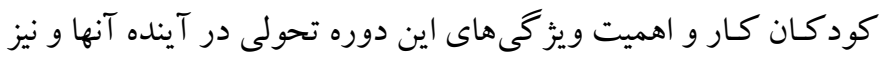

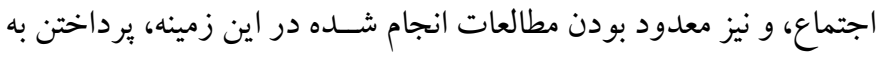

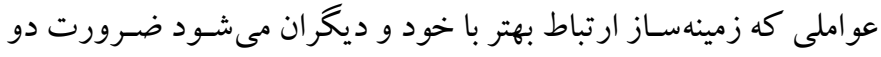

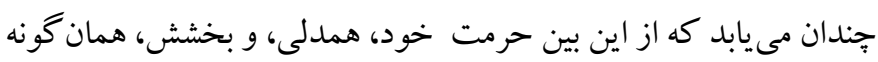

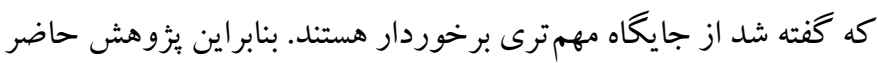

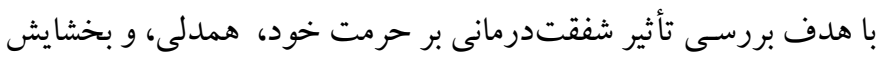
كود كان كار انجام شد. الف) طرح هزوهش و شــر كت كنند كان: طرح بزوهش حاضـر از نوع

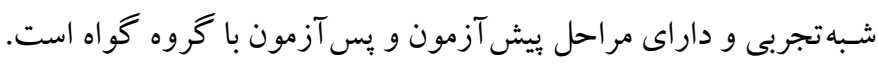

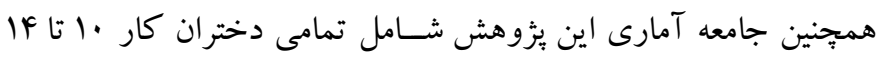
سـاله شـاغل به تحصيل در مؤسسـه صـبح رويش (استان تهران) در سال
نوجو انان متمر كز شــده اسـت، اما درمان متمر كز بر شـفقت، روى آوردى يكيارجهنگر اسـت كه سـعى كرده تا بر شـكاف سـنتى مابين هيجان و

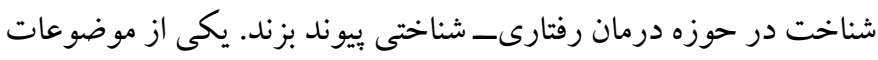

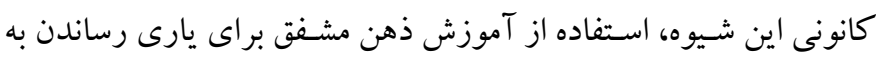
افراد و ايجاد ملايمت درونى، امنيت و تسـكين از طريق شـفت به به خود و ديخران است (19). همجِنين درمان متمر كز بر شــقتت به خصــوص براى درمان افرادى

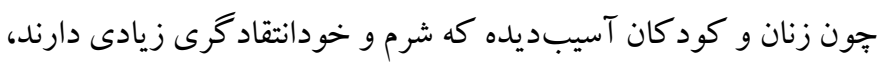

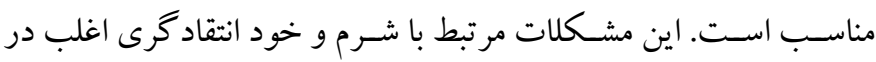

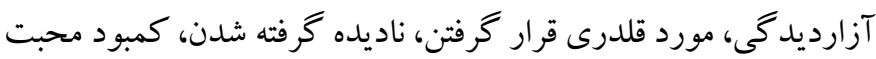

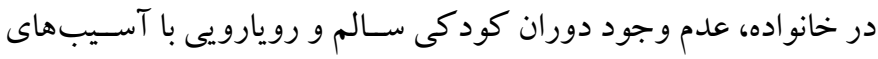

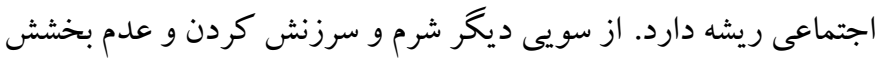

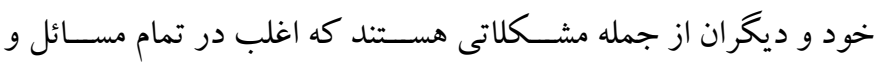

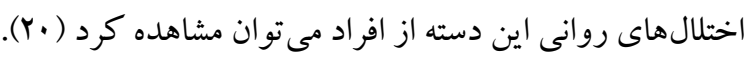
با اين وجود تعدادى از بزوهش ها به اثربخشى تمرين هاى خودشفقتى

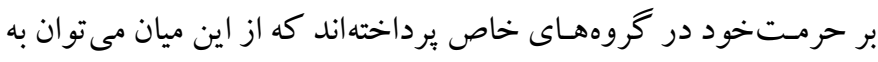
سعادتى، رستمى و دارابى (V) اشاره كرد كه از مطالعه خود نتيجه كرفتند،

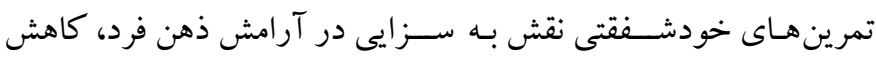

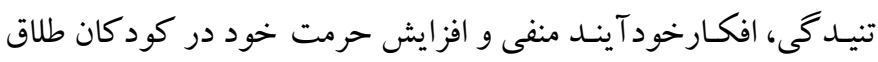
خواهد داشـت. همجِنين اثربخشى اين درمان در برخى از مطالعها مورد

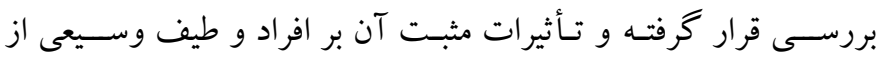

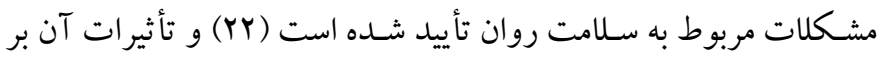

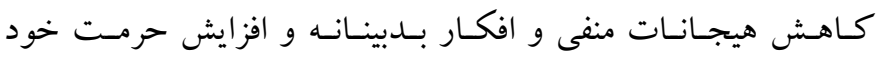

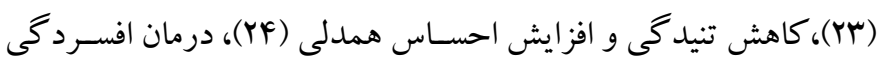

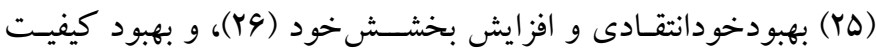

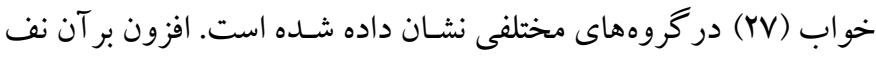

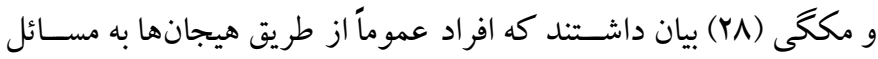

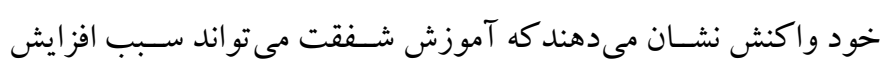
حرمت خود و بخشـش خود شـود تا فرد خود را براى مقاومت و دفاع در برابر آن مسائل يا اجتناب از آن آماده كند.

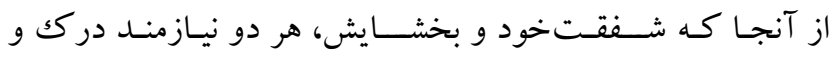

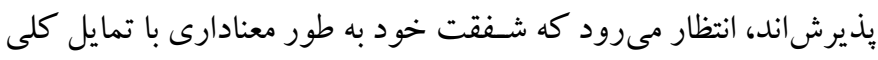


كه بايين تر از اين نمره به دســت آورد داراى حرمت خود بايين اســت.

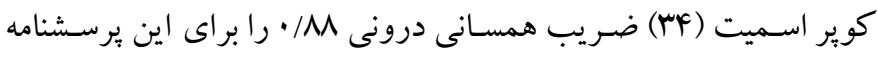

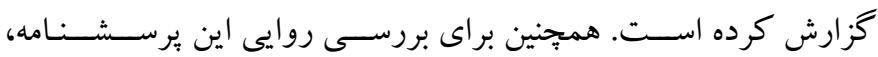

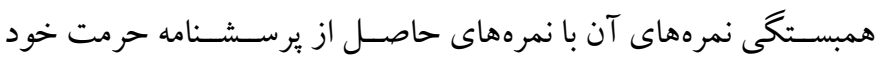

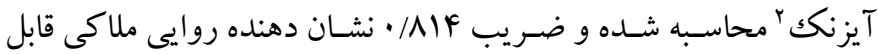

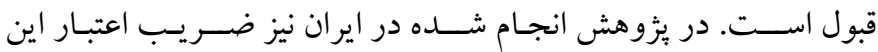

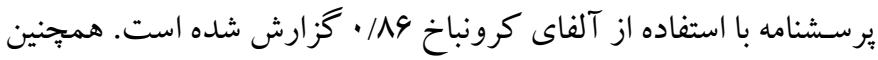

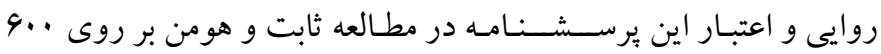

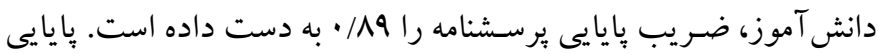
ابزار نيز از طريق باز آزمايى انجام شد كه ضريب MM/• را بس از هـ هفته و

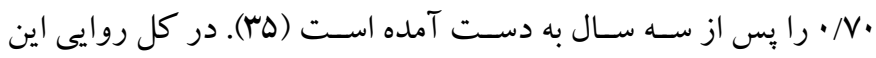
يرسشـنامه در يُزوهش هاى بيشـين قابل قبول ارزيابى شده است. همجينين

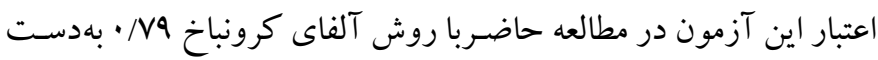

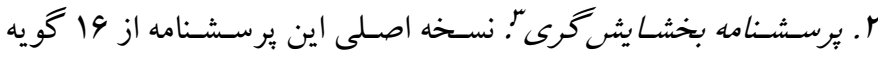

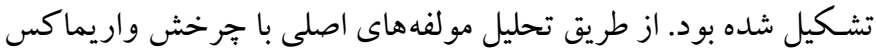

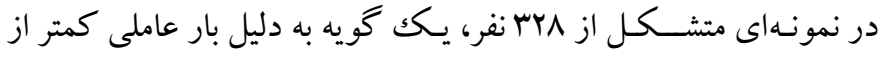

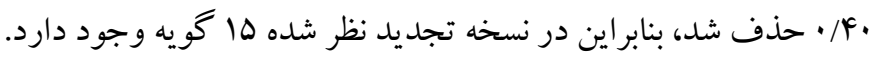

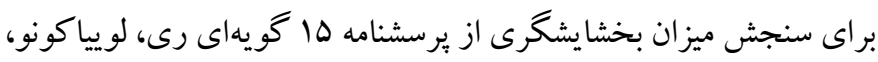

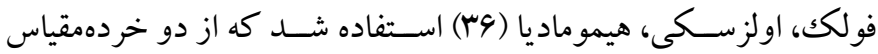

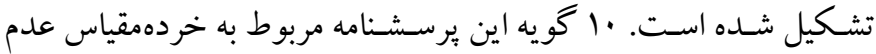

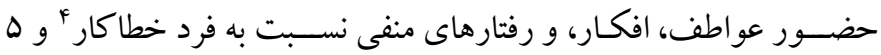

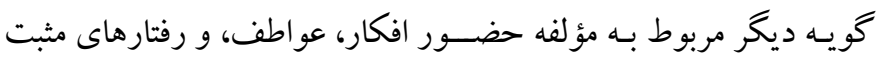

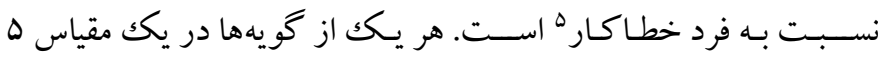

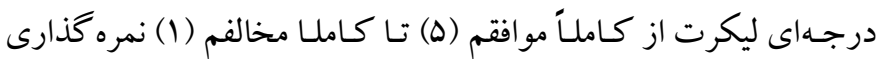
مىشـوند و نمرات بيشتر، نشـان دهنده سطح بالاتر بخشش شخص است.

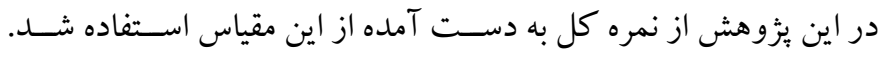

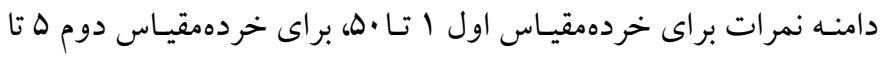

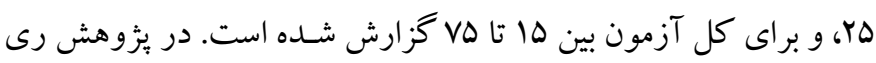

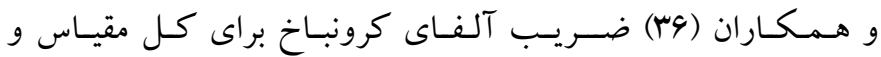

4. Absence of negative thoughts, and behavior toward wrongdoer 5. Presence of positive thoughts, and behavior toward wrongdoer

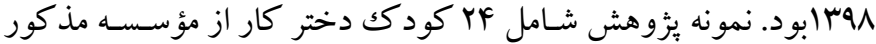
بوده اسـت كه از طريق نمونه گيرى در دسترس و بر حسب شرايط ورود بـه بزظوهش انتخاب شــدند و به تصــادف در دو گروه آزمايش و گگواه جايدهى شـدهاند. ميانگين سـنى افراد نمونه در دو گروه آزمايش و گو اه

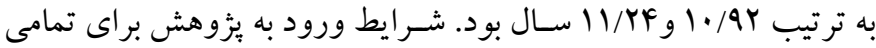
افراد نمونه عبارت بود از: دامنه ســنى ·ا تا f| سـال، وضـعيت در حال تحصـيل، زندكى با والدين، برخوردارى از وضـعيت هوشسى بهنجار، و نداشـتن نقص جسـمانى (اين اطلاعات از يرونده مشـاوره دانش آموزان به دســت آمـد) بود. شـــرايط خروج از يزووهش نيز شــامل عدم همكارى كودك و عدم رضـايت والدين بود. همجينين گروه آزمايش تحت برنامه درمانى هشــت جلســاى شــفتتدرمانى قرار گرفتند و گروه گو اه فقط روند آموزش هاى معمول در مدارس را دريافت مى كردند.

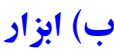
ا . يرسشنامه حرمت خود كوير /سميت ': در اين مطالعه براى اندازه كيرى حرمت خود از برسـشـنامه حرمت خود كوير اسـميت (MF) اسـتفاده شـد.

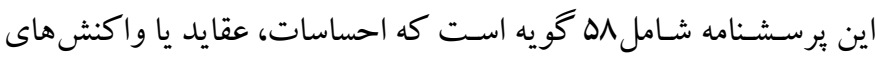
فرد را توصسيف مى كند و آزمودنى بايد متناسـب با وضعيت خود يكى از كزينهاى بلى يا خير را انتخاب كند. آزمودنى به كويههاى برسـشنامه بر حسب مفهوم آن ("به من شبيه است"، بلى و يا "به من شبيه نيست "(خير) ياسـخ مىدهد. شيوه نمره كذارى در اين برسشنامه به صورت صفر و يك اسـت و ^ گ گ يه آن به دروغسنج اختصاص داده شده است و در محاسبه نمره كل، اين ^ گويه منظور نمىشـود. ·ه گويه ديخر آن F خردهمقياس

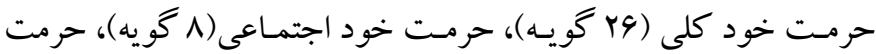

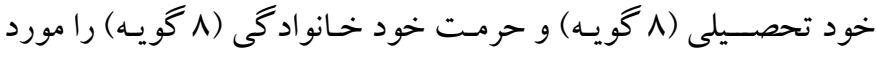
ســنجش قرار مى دهـــ. نمرات به دســت آمده، امكان مشــخص كردن زمينـهاى را كه در آن افراد واجد تصــوير مثبتى از خود هســتند، فراهم مىسـازد. بديهى اسـت حداقل نمرهاى كه يكك فرد مى تواند كسـب كند صــر و حداكثر آن ·ه اســت. افرادى كه در اين آزمون نمره بيشــترى كسـب كنند، حرمت خود بالاترى دارند؛ به اين صسورت كه فردى كه در اين آزمون نمره بالاتر از ها را كسب كند داراى حرمت خود بالا و فردى

1. Cooper Smith Self-esteem questionnaire

2. Eysenk self-esteem questionnaire-1976

3. Forgiveness questionnaire 
نمره •ll اسـت. للازم به ذكر اسـت كه در اين ئزوهش براى اندازهيرى

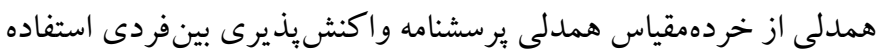

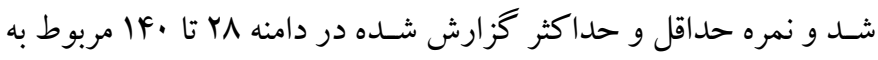
نمره كل يرسشنامه است. ديويس ضريب كرونباخ را براى اين مقياس در

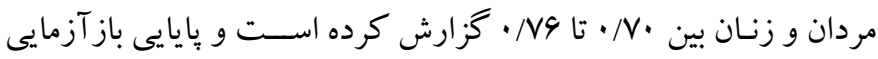

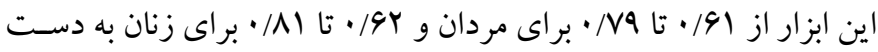

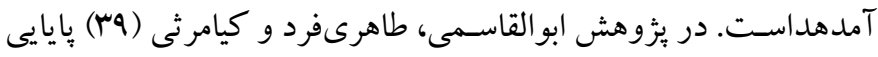

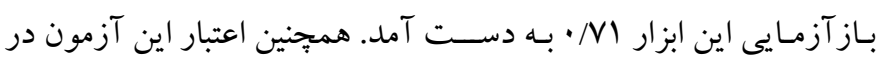

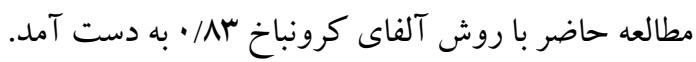
ج) برنامه مداخلهاى: برنامه مداخلهاى به كار گرفته شده در اين مطالعه،

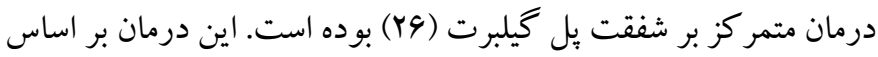

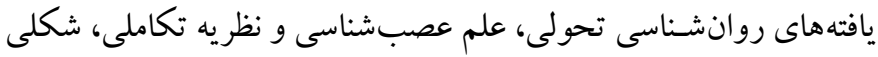
جامع از رفتاردرمانى تجربى را تدوين كرده است كه به نام درمان متمركز

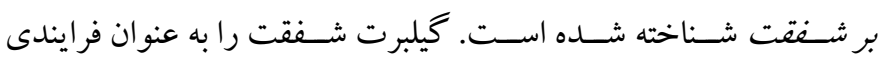
جندوجهى توصسيف مى كند كه از ذهنيت مراقبت كننده، تكامل يافته و در مراقبـت والدينى و يرورش كودكك نمود ييدا مى كند. شـفقت داراى

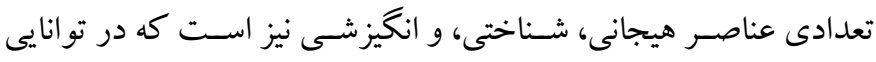

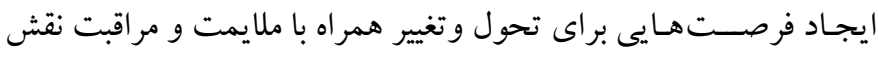

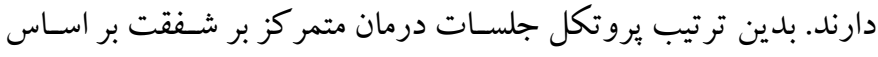

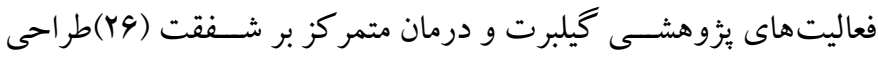

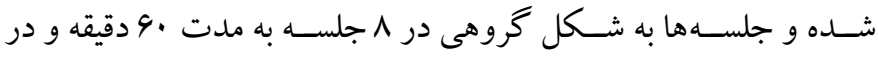
روزهاى شـنبه و دوشــبه هر هفته در مدرسـه صـبح رويش اجرا شـــ در جدول ا، خلاصسه سـاختار كلى درمان متمركز بر شفقت بر اساس مفاهيم كيلبرت ارائه شده است. تلاصن.

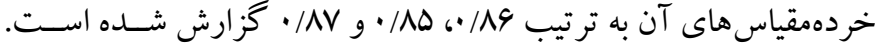

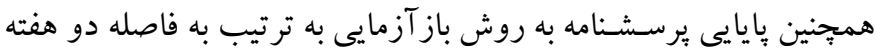

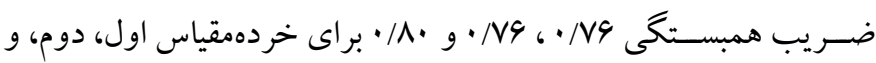

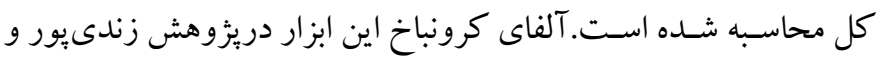

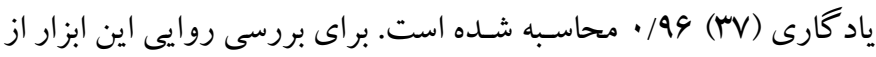

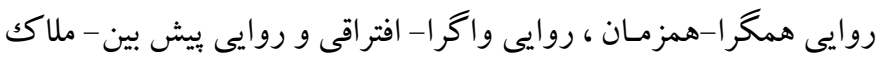

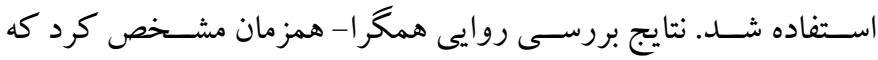

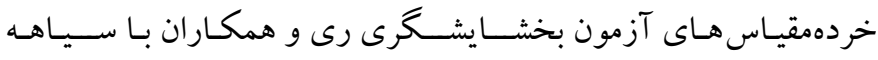

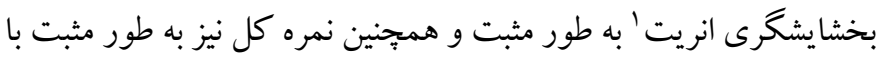

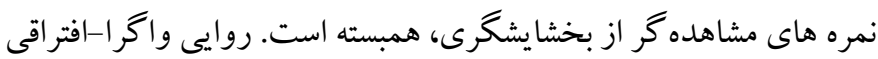

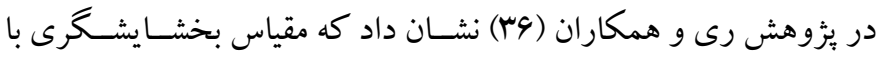
شـاخص هاى سـلامت روان مانند بيان خشـم و صـفت خشـم و همجِنين

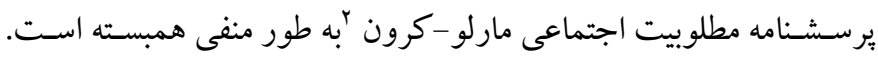

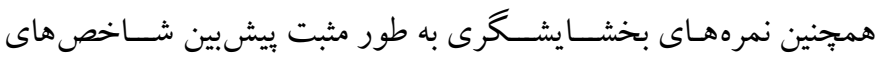
ســلـامت روانى مانند بهزيسـتى وجودى و بهزيسـتى معنوى بودند.اين

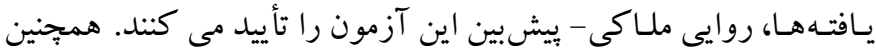

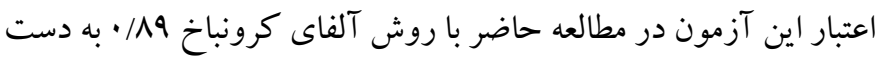

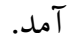

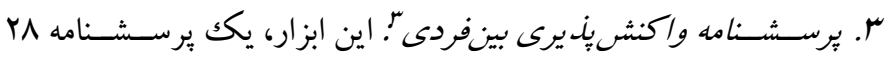

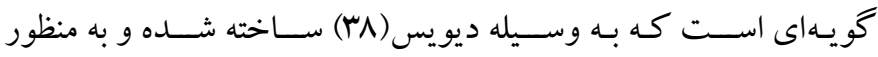

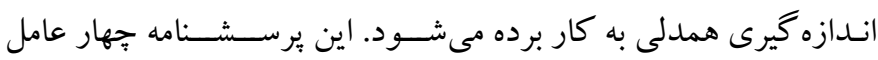

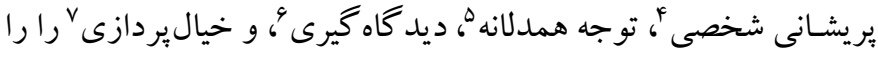

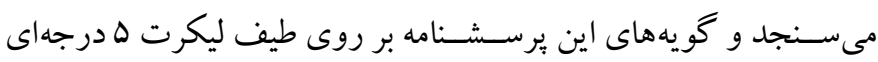

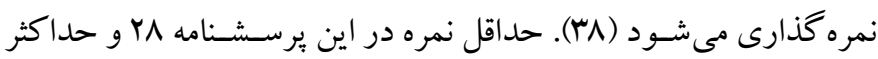

جدول ا: ساختار كلى درمان متمر كز بر شفقت بر اساس مفاهيم تيلبرت

\begin{tabular}{|c|c|c|c|c|}
\hline رفتار مورد انتظار & تمرين خانكى & محتواى جلسات & اهداف & جلسات \\
\hline 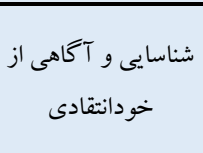 & 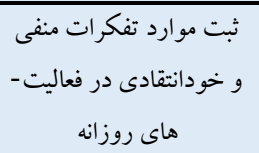 & 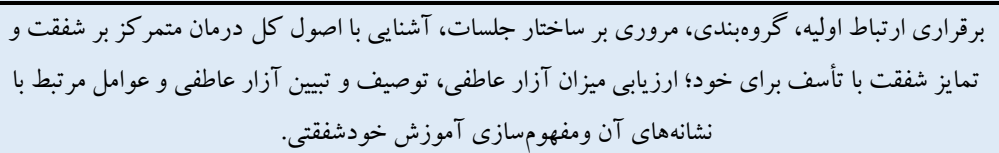 & كلى درمايى با اصول & 1 \\
\hline
\end{tabular}

5. Empathic Concern 6. Perspective taking 7. Fantasy
1. Enright forgiveness inventory-1991

2. Marlowe-Crown social desirability scale- 1960

3. Interpersonal reactivity index

4. Personal distress 


\begin{tabular}{|c|c|c|c|c|}
\hline مؤلفه هايى خودشفقتى آكاهى از & 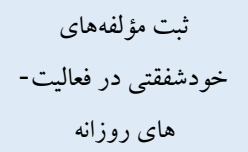 & 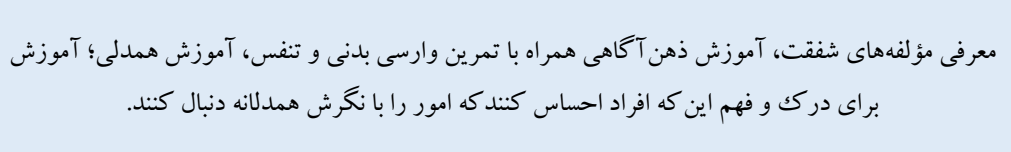 & شناخت مؤلفههاى & r \\
\hline 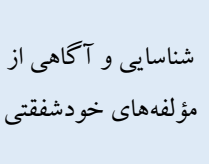 & 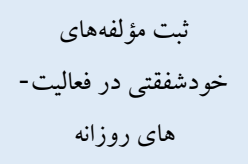 & 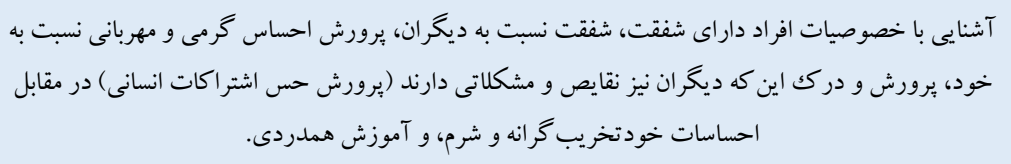 & خود شفق آموز يروش اعضا & $r$ \\
\hline يرورش خودشفقتى & ثبت اشتباهات روزانه و & 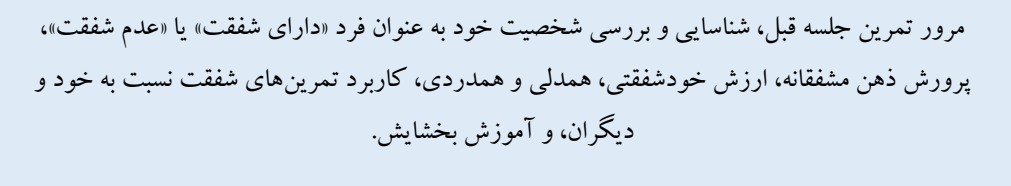 & خوناسايى عوامل خوداسى و خوانتقادى & f \\
\hline خ بهودشفو و توسعتى & 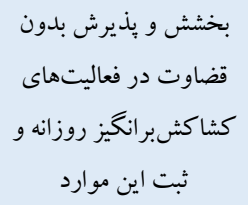 & 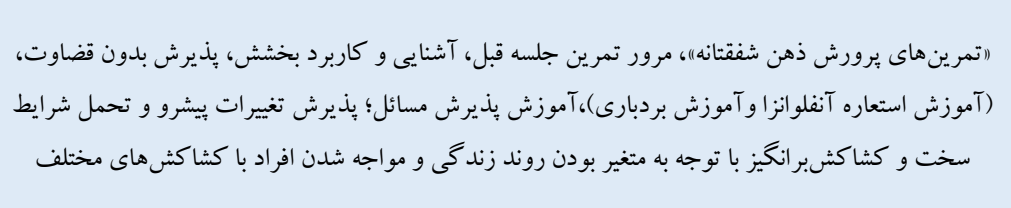 & اصلاح و گسترش شفت & $\Delta$ \\
\hline خ خوشفقتى ارزشمندى و & فاله كارگيرى شفقت در & 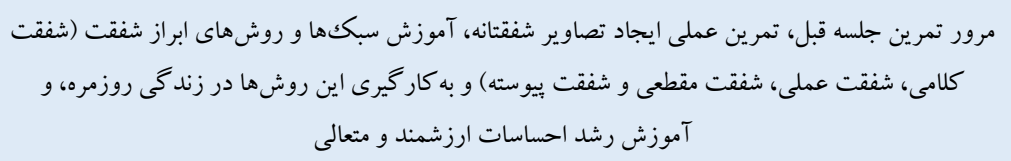 & روش هاى ابزار & 4 \\
\hline خوبود خوارزشمندى بو و & آنوشت نامه هاى شفقت - نواى خود و ديخران & 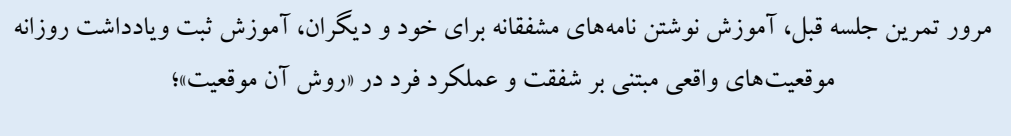 & فنون ابزار شفقت & $\checkmark$ \\
\hline خ خ خودش وشفتى رشد & 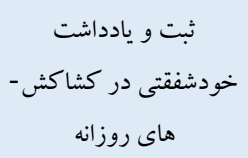 & 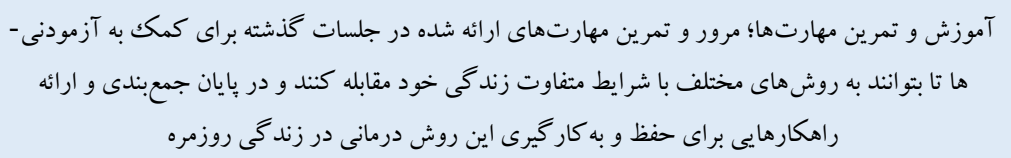 & ارزيابى و كاركرد & $\wedge$ \\
\hline
\end{tabular}

يايان مداخله، برسـشنامههاى مربوط به متغيرهاى وابسته ئزوهش در نوبت اجراى دوم توسط تمامى كود كان دو گروه تكميل شـدند. سـيس تمامى يرســـــــامسها جمع آورى و تجزيه و تحليل دادهها با آزمون تحليل كوواريانس يكر اهه انجام شد.

\section{يافتهها}

براى بررسى فرضيه نخست اين يزوهش يعنى تأثير مداخله شفقت درمانى

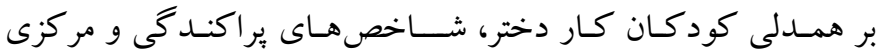
كروههاى آزمايش و كو اه در مراحل ييش آزمون و بِ آزمون در جدول

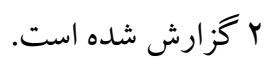

د) روش اجرا: يس از كسـب مجوزهاى لازم از آموزش و يرورش و مراجعه به مؤسسه صبح رويش كود كان كار دختر منطقه 19 شهر تهران، اطلاعات كلى در مورد كود كان به دست آمد. سـبس FF نفر از كود كان كار دختر به شيوه در دسترس و با توجه به ملاككهاى ورود و خروج ذكر شــده در بخش روش، از اين مؤسـسـه انتخاب شــنـد. در مرحله بعد اين كود كان به شـيوه تصـادفى به دو گروه آزمايش و گو اه جايدهى شـدند. يرسـشـنامه هاى حرمت خود، بخشـايش كرىى، و واكنش يذيرى بين فردى بين كود كان هر دو گروه طى روزهاى متوالى توزيع و با رضايت كامل و آكاهانه تكميل شـد. بعد از تكميل برسـشـنامهها در مرتبه اجراى نخست، مداخله شـفتت ورزى به مدت ^ جلسـه ،و دقيقهاى به روش گيلبرت در روزهاى شـنبه و دوشـنبه براى گروه آزمايش اجرا شـد و در نهايت و در 
جدول r: شاخصهاى مركزى و يراكندكى دو كروه در متغيرهاى يزوهش

\begin{tabular}{|c|c|c|c|c|c|c|c|}
\hline \multirow{2}{*}{ كشيدَى } & \multirow{2}{*}{ جولَّى } & \multicolumn{2}{|c|}{ 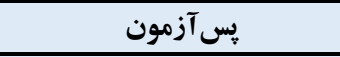 } & \multicolumn{2}{|c|}{ بيش آزمون } & \multirow{2}{*}{ كروه } & \multirow{2}{*}{ متغير ها } \\
\hline & & انحراف معيار & ميانكين & انحراف معيار & ميانكين & & \\
\hline$\cdot / I F A$ & $\cdot / T Y A$ & $9 / 19$ & $\mathrm{rV} / \cdot \mathrm{I}$ & $11 / V \Delta$ & IV/rT & آزمايش & \multirow{2}{*}{ همدلى } \\
\hline$\cdot / r \cdot 1$ &.$/ 191$ & $1 r / 90$ & $r \Delta / r \Delta$ & $1 Y / \Delta Q$ & $\mid \Delta / \cdot \Lambda$ & كو اه & \\
\hline$\cdot / I r \wedge$ & . /YYI & $9 / 19$ & $r 8 / \cdot 1$ & $1 . / \mathrm{V} 9$ & $r Y / \cdot 1$ & آزمايش & \multirow{2}{*}{ بخش } \\
\hline •/KTD & $\cdot /$ YVA & $1 \cdot / \mathrm{VI}$ & $r r / v i$ & $1 \cdot / W$ & $r \cdot / 41$ & كواه & \\
\hline . IFF &.$/ 194$ & $r / 90$ & $r 9 / 19$ & $r / v \Delta$ & $r \cdot / I r$ & آزمايش & \multirow{2}{*}{ حرمت خود } \\
\hline$\cdot / 1 \Delta \wedge$ & $\cdot /$ YFD & $r / 4 i$ & $1 F / 19$ & $r / \Delta 1$ & $1 r / V$ & كواه & \\
\hline
\end{tabular}

متغير بزوهش در دو گروه از آزمون لوين اسـتفاده شـد. از آنجا كه سطح

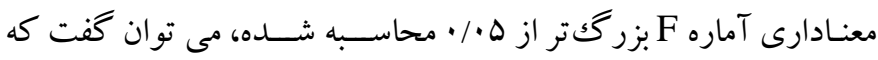
واريانس خطاى گروه ها با همديگر برابر بوده و تفاوتى بين آنها مشـاهده

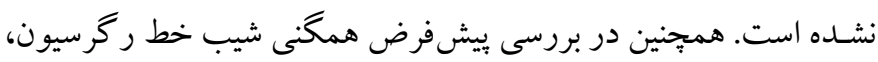

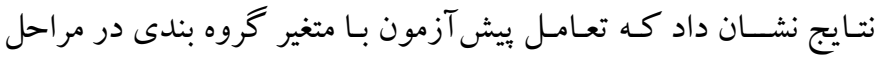

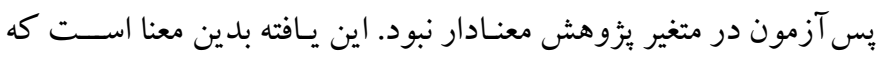
فرض همخنى شيب خط رگرسيون در اين متغير برقرار است و در نتيجه

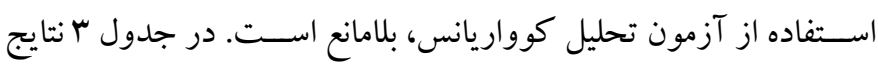

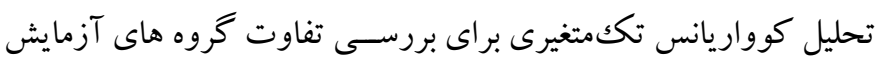
و گواه در متغير همدلى گزارش شده است.
بر اسـاس نتايج جدول r در متغير همدلى، بررسسى ميانگين دو گروه

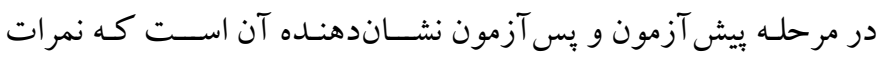

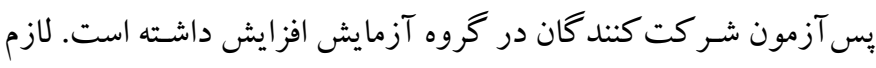
به ذكر اسـت در اين آزمون كسـب نمره بالاتر نشـاندهنده همدلى بيشـتر اسـت. به منظور اثربخشى مداخله شفقت بر همدلى كود كان كار دختر از آزمون تحليل كوواريانس اسـتفاده شـد. اسـتفاده از اين تحليل، مسـتلزم رعايت بيشفرضهايى است كه بيش از اجراى آزمون مورد بررسى قرار

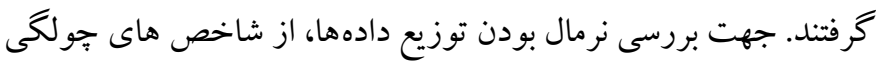

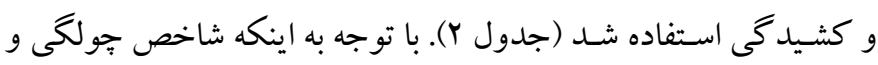

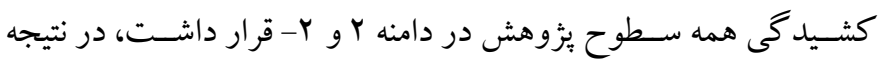

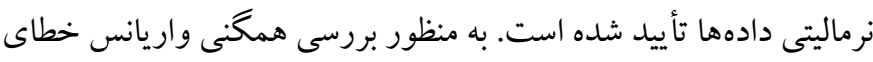

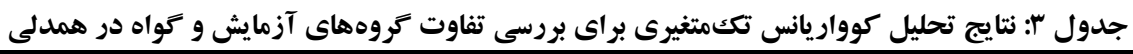

\begin{tabular}{|c|c|c|c|c|c|c|c|c|}
\hline توان آمارى & ضريب اتا & سطح معنى دارى & $\mathbf{F}$ & ميانكين مجذورات & درجه آزادى & مجموع مجذورات & منبع تغييرات & متغير \\
\hline 1 &.$/ 910$ &.$\cdot \cdot 1$ & $\Delta Q / \wedge \Delta$ & $19 \mathrm{VTO} / \mu \mathrm{r}$ & 1 & 19VTO/RT & ي يَش آزمون & \\
\hline.$/ \Delta r$ &.$/ \cdots 9$ & $\cdot / 10$ & $r / 1$. & $\Delta M$ & 1 & $\Delta M$ & كروه & همدلى \\
\hline - & & & & & r) & ONGN/94 & خطا & \\
\hline
\end{tabular}

شـده اسـت. براساس نتايج جدول r در متغير بخشش، بررسى ميانگين دو

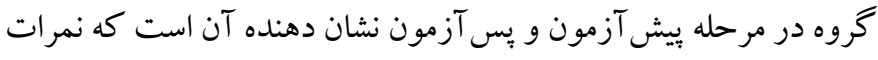

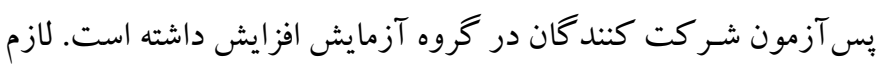

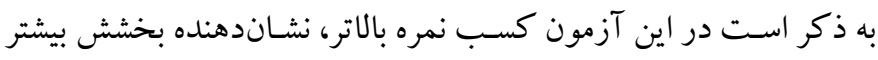

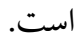
به منظور اثربخشى مداخله شـفقت بر بخشـش كود كان كار دختر از

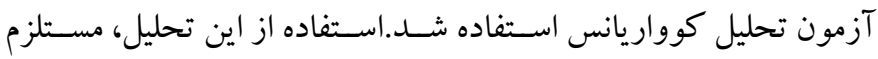
رعايت بيشفرض هايى است كه بيش از اجراى آزمون مورد بررسى قرار
بـا توجـه بـه جـدول س، آمـاره F متغير همدلى در بس آزمون (·Y/I)

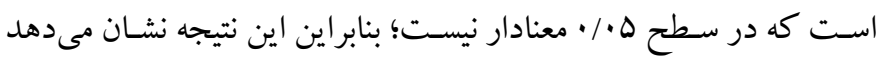

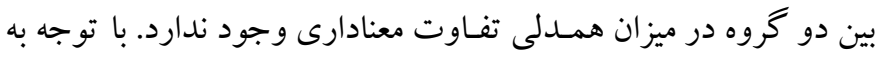

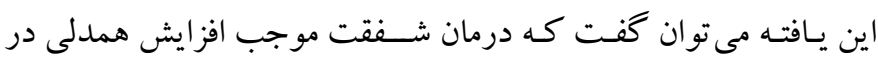
كود كان كار دختر نشده است. براى بررسـى فرضسيه دوم يعنى اثربخشى مداخله شـفقت درمانى بر

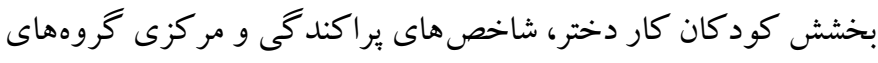

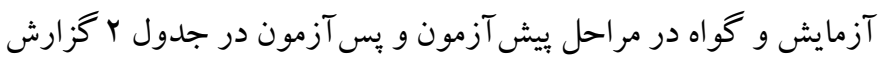


مشـاهده نشــده اسـت. همجِنين در بررسى ييشفرض همخنى شـيب خط ركرسـيون، نتايج نشـان داد كه تعامل ييش آزمون با متغير گرووبندى در مر احل بِ آزمون در متغير بثروهش معنادار نبود. اين يافته بدين معنا است كه فرض همكنى شيب خط رگ گريون در اين متغيربرقرار است. در نتيجه اســفـاده از آزمون تحليـل كوواريانس بلامانع اســت. در جدولث نتايج تحليل كوواريانس تككمتغيرى براى بررسى تفاوت گرووهاى آزمايش و كو اه در متغير بخشش گزارش شده است.
كرفتند. جهت بررسى نرمال بودن توزيع دادهها، از شاخص هاى جورلىى و كشـيدكى اسـتفاده شـد (جدول Y). با توجه به اينكه شاخص جولكى و

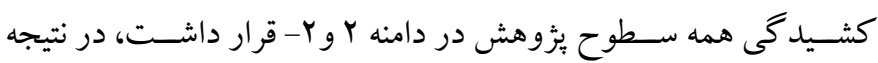

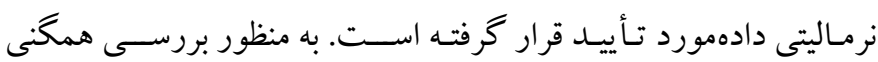
واريانس خطاى متغير يزوهش در دو گروه از آزمون لوين استفاده شد. از آنجا كه سطح معنادارى آماره F بزرگكتر از هـ • • محاسبه شده، مى توان كفت كه واريانس خطاى گروهها با همديخر بر ابر بوده و تفاوتى بين آنها

جدول ع: نتايج تحليل كوواريانس تكمتغيرى براى بررسى تفاوت كروههاى آزمايش و كواه در بخشش

\begin{tabular}{|c|c|c|c|c|c|c|c|c|}
\hline توان آمارى & ضريب اتا & سطح معنى دارى & $\mathbf{F}$ & ميانكين مجذورات & درجه آزادى & مجموع مجذورات & منبع تغييرات & متغير \\
\hline.$/ 999$ & $\cdot / \Delta \Delta$ &.$/ \cdot 1$ & $1 \wedge \Delta / V V$ & Mr^GV/IA & 1 & $r r \wedge 9 V / M \Lambda$ & ييش آزمون & \\
\hline$\cdot / \cdot \Delta \Lambda$ & .1 .11 & 年/ &.$/ 94$ & $1 \wedge \cdot / 11$ & 1 & $1 \Lambda \cdot / 11$ & كروه & بخش \\
\hline - & & & & & r) & $f .11 / 1 r$ & خطا & \\
\hline
\end{tabular}

هـاى آزمـايش و كواه در مراحل بيش آزمون و يس آزمون در جـدول Y گز ارش شــده اســت. بر اسـاس نتايج جدول ب در متغير حرمت خود، بررسى ميانگين دو گروه در مرحله ييش آزمون و يس آزمون نشاندهنده

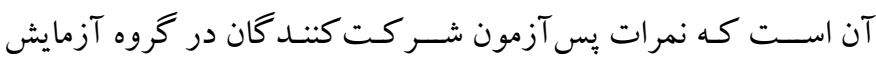
افزايش داشـه اسـت. لازم به ذكر اسـت در اين آزمون كسب نمره بالاتر،

$$
\text { نشان دهنده حرمت خود بيشتر است. }
$$

بـا توجسه بـه نتـايج جـدول F، آماره F متغير بخشـش در يس آزمون

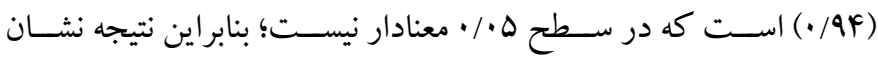
مىدهـد بين دو كروه در ميزان بخشـش تفـاوت معنـادارى وجود ندارد. بـاتوجـه بـه اين يـافتـه مى توان كفـت كه درمان شـفقت موجب افزايش بخشش در كود كان كار دختر نشده است. بر اي بررسـى فرضسيه سـوم يعنى اثربخشى مداخله شـفقت درمانى بر

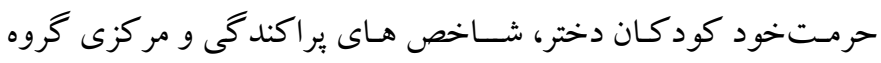

جدوله : نتايج تحليل كوواريانس تكمتغيرى براى بررسى تفاوت كروههاى آزمايش و كواه در حرمت خود

\begin{tabular}{|c|c|c|c|c|c|c|c|c|}
\hline توان آمارى & ضريب اتا & سطح معنى دارى & $\mathbf{F}$ & ميانكين مجذورات & درجه آزادى & مجموع مجذورات & منبع تغييرات & متغير \\
\hline.$/ 991$ & $\cdot / 4 \wedge q$ & $\% / \cdot 1$ & $V H N / H_{F}$ & $190 \cdot Y / \cdot 1$ & 1 & $190 \cdot r / \cdot 1$ & يِش آزمون & \\
\hline ./VGV & - /TFA & $\cdot / \cdot 1$ & $F \Delta / 9 q$ & $1.1 V / \Delta r$ & 1 & $1.1 V / \Delta r$ & كروه & حرمت خود \\
\hline - & & & & & $r$ & $899 / \% q$ & خطا & \\
\hline
\end{tabular}

\section{بحث و نتيجه تيرى}

يزٔوهش حاضر با هدف بررسى اثربخشى مداخله شفقت درمانى بر حرمت خود، همدلى، و بخشايش در كود كان كار 9 الى fl السال انجام كرفت. به طور خلاصه نتايج نشان داد كه مداخله مذكور سبب افزايش حرمت خود كودكان كار دختر مىشود. از سويى ديكر با وجود افزايش بخشش و همدلى در گروه آزمايش، تغييرات آن نسبت به گروه گواه معنادار نبود.
بـا توجسه بـه نتـايج جدول ه، آماره F متغير بخشــش در يس آزمون (FD/99) به دسـت آمد كه در ســح ه • • معنادار اسـت. بنابراين نتيجه نشـان مىدهد بين دو گروه در ميزان حرمت خود تفاوت معنادارى وجود دارد. اندازه اثر YFA • نيز نشـان مىدهد كه اين تفاوت در جامعه براساس معيار كوهن بزرك اســت. با توجه به اين يافته مىتوان كفت كه درمان شفقت موجب افزايش حرمت خود در كودكان كار دختر شده است. 
عواملى كه كود كان كار در سطح خانواده، محله و حين كار با آن مواجه

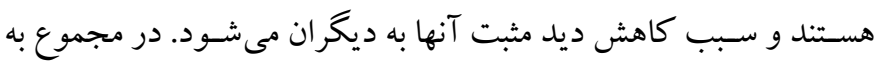

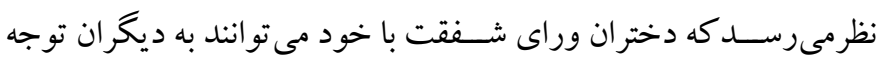

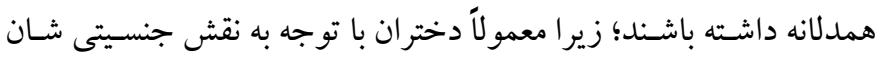

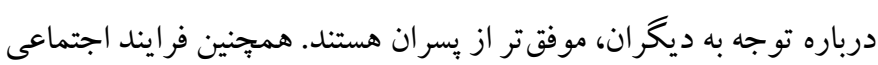

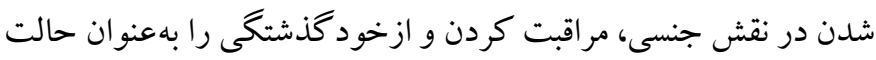

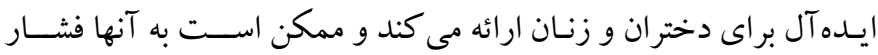

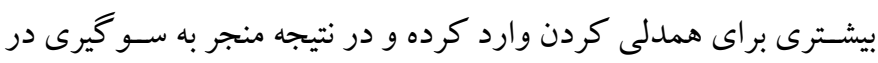
ياسخ هاى آنان مى شود.

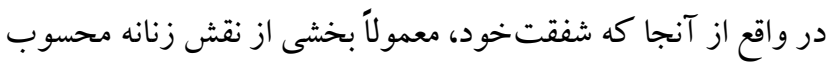
نمىشود، زنان بيشتر مايل هستند خود را به عنوان كسى ببينند كه دلسوز

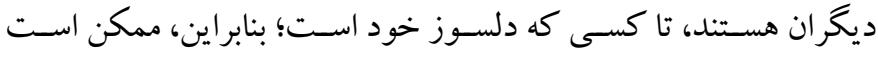

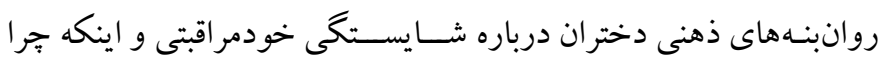

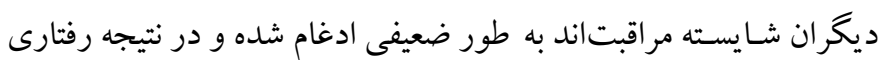

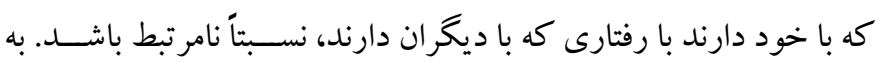
عبارت ديخر، در دختران عامل همانندسازى افراطى بيشترين تأثير معنادار

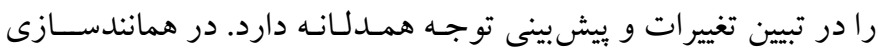

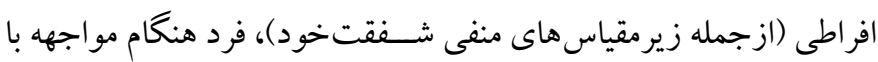

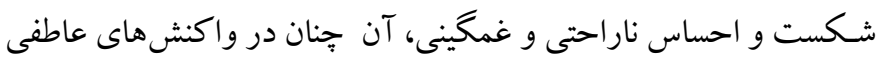

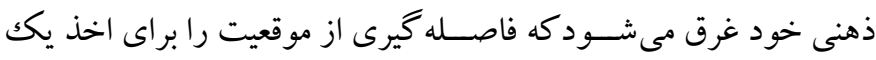

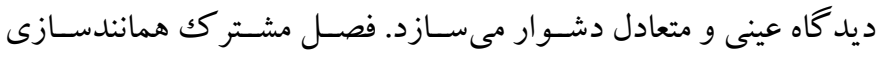

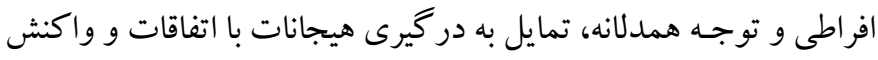

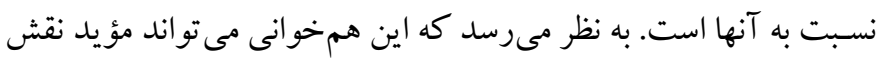

ييشبين همانندسازى افر اطى براى توجه همدلانه در دختران باشد.

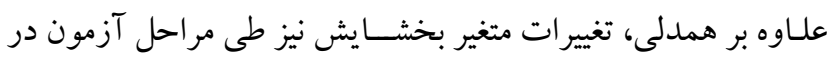

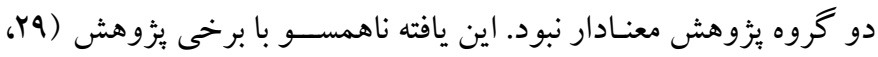

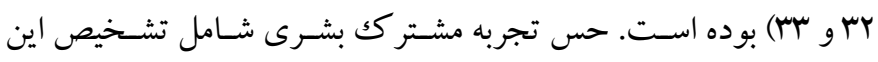

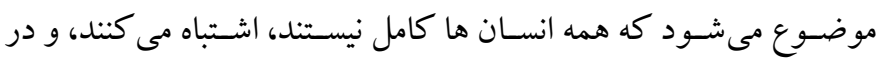

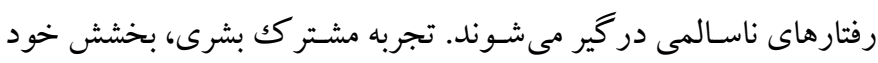
به خاطر انسـان بودن، محدود و ناكامل بودن را شـامل مىشـود. درنتيجه اذعان به خطاكارى و ناقص بودن، امكان بخشـايش خطاهاى ديخران را

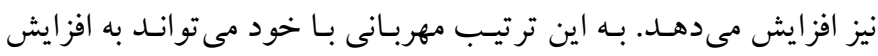

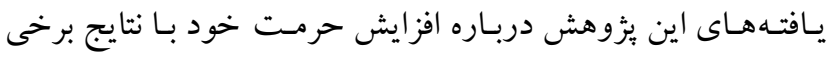

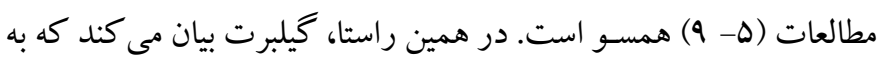

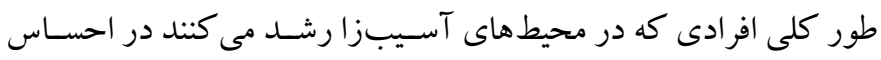

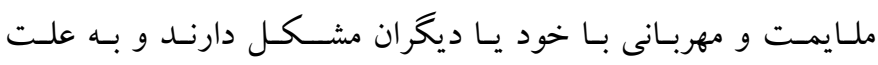

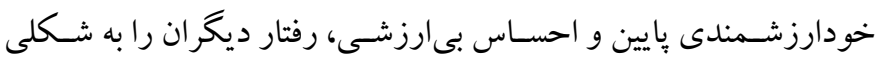

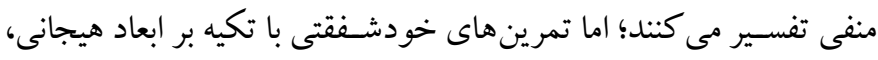

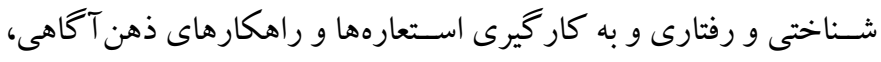

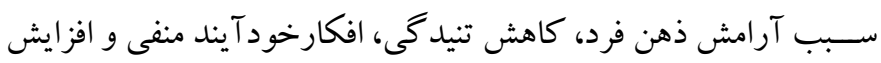

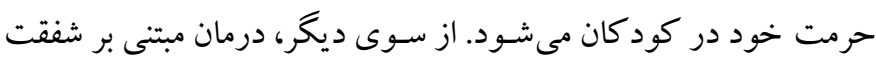

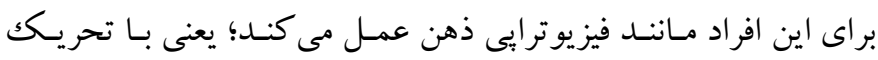

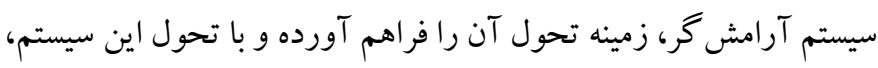

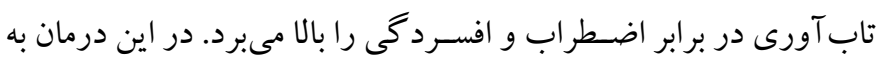

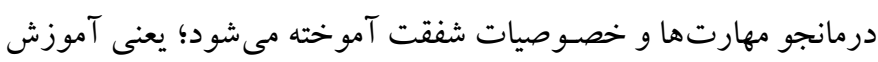

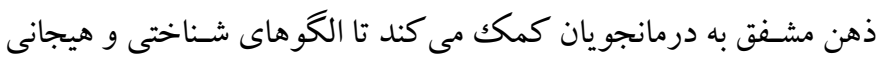

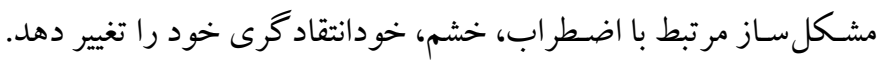

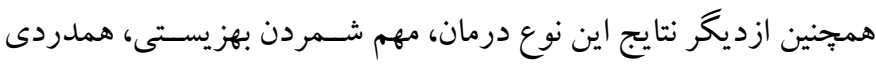

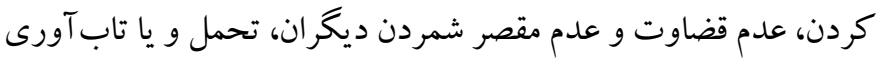

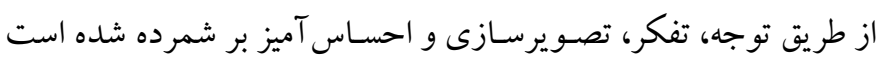
امـا از ديخر نتايج اين بزوهش تغييرات معنادار گروههاى بزوهش در

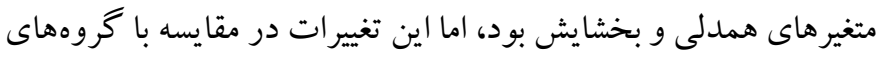

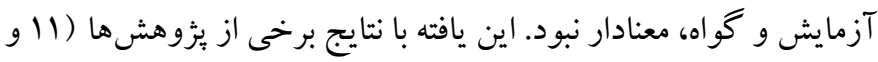

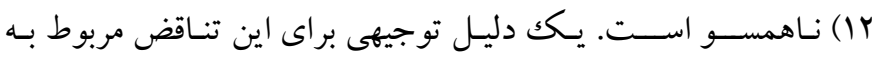

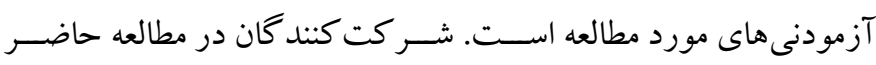

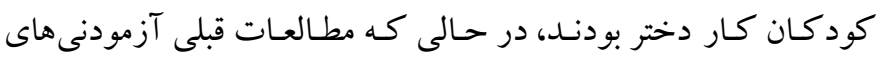

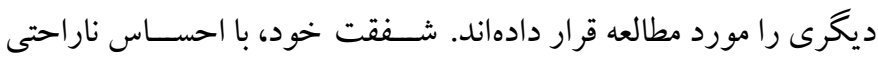
شـخصى كمتر با واكنش به شـخص ديخر، همر اه اسـت، اما اكر شـرايط

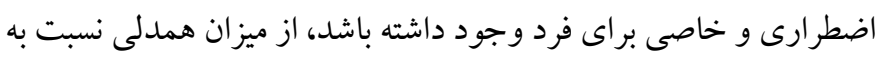

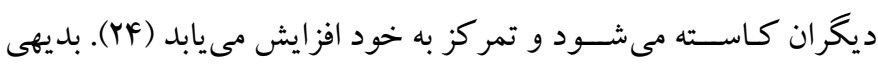

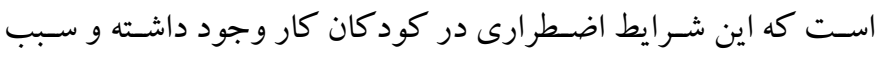

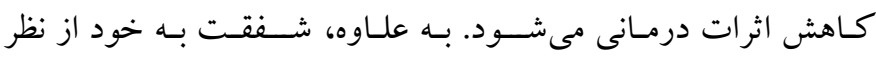

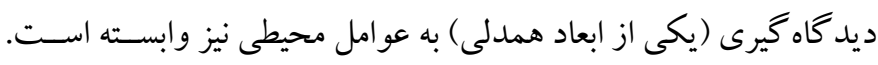


درمانى و روانشناختى، اثر بافت فرهنگى و جنسيت در نظر گرفته شده و درمان براى اين گروه متناسبسازى شود.

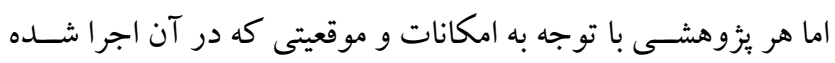

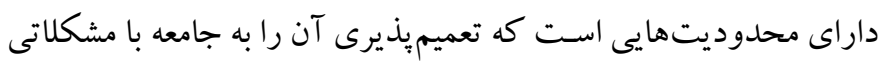

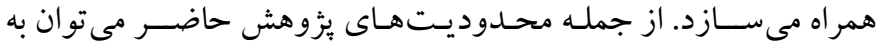

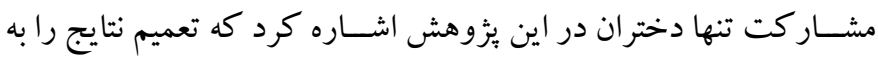
توجه به تفاوت شـاخصسهاى در كك يسـران با محدوديت مو اجه مى كند.

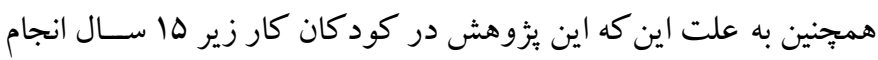
شده است، بايد در تعميم آن به دختران بهنجار و ساير سنين احتياط كرد. علـاوه براين بـايـــ در نظر داشـــت كـه ابزارهـاى اين ئزوهش از نوع

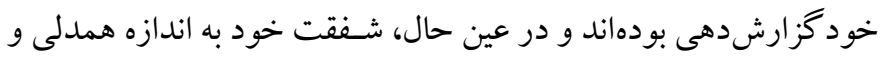

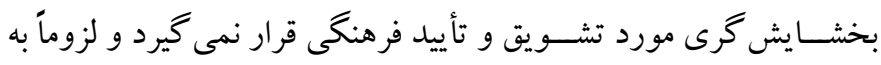

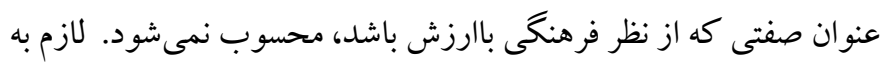

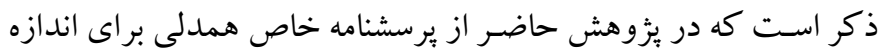

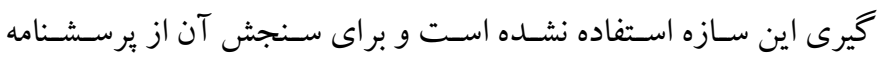
واكنش يـذيرىبين فردى بـا F خردهمقياس كه يكى از زيرمقياس هاى آن

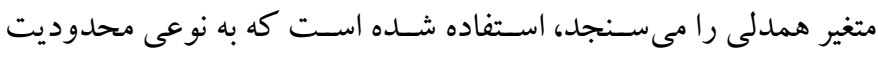
روششناختى اين مطالعه به حساب مى آيد.

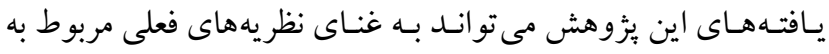

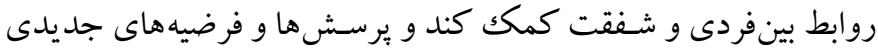

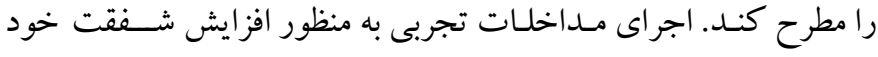
مى تواند وضوح بيشترى به اين مطالعات ببخشد. بنابر اين، ييشنهاد مى شود

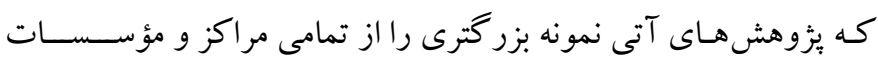

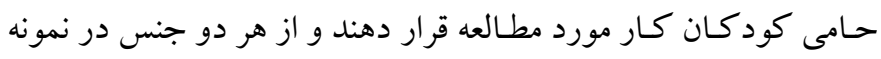

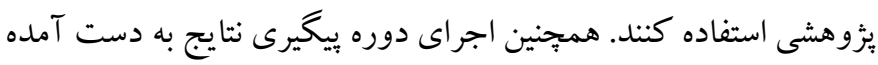

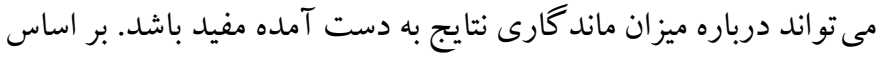

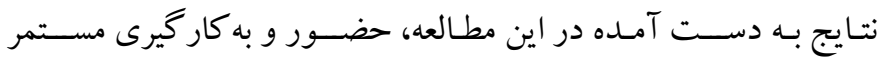

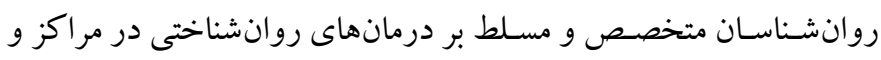

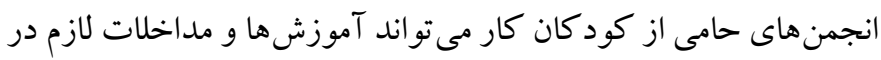

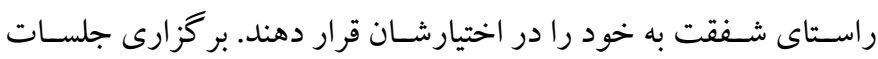
آموزشى هنتخى با حضـور روانشناسان به منظور ياسخ كويى به سؤ الات

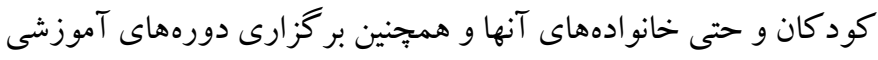

مهربانى با ديخران منجر شـود؛ اين در حالى اسـت كه در گروه خاصسى

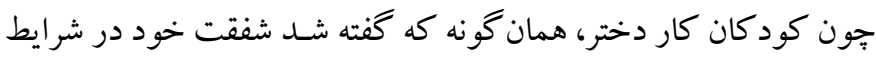

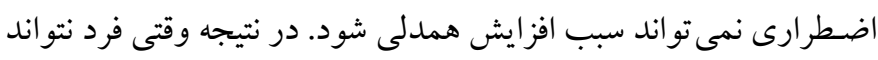

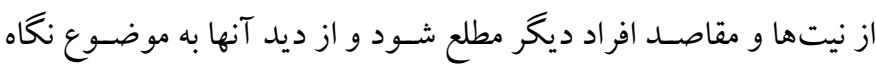
كند، سـبب مى شـود در كك درستى از موقعيت حاصـل نشـده و در نتيجه

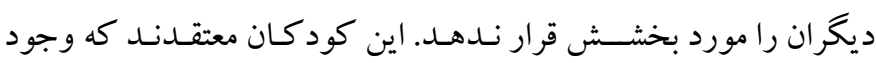

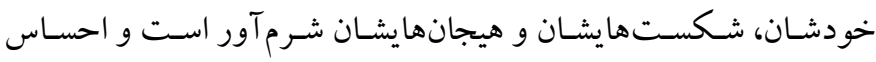

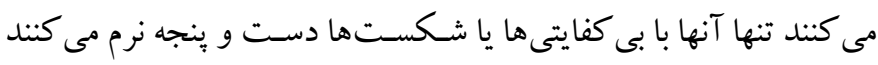

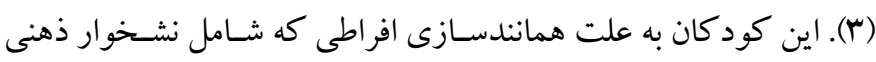
در مورد محسدوديتهاى خود اسـت و منجر به ديد تونلى مىشــود، از

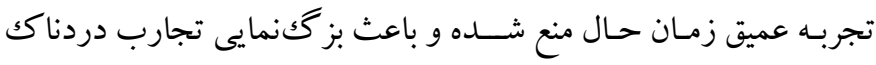

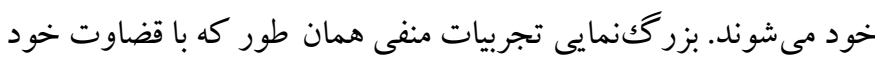

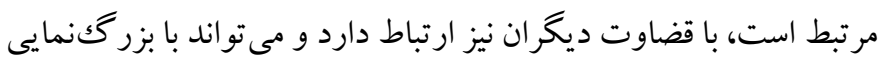

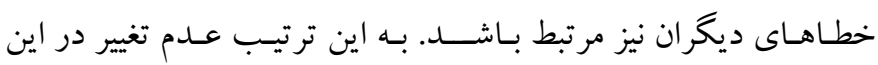

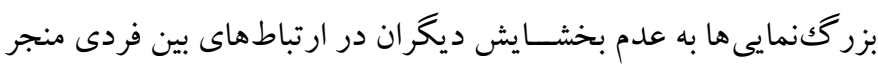
مىشـود. همجنين، اين كود كان ممكن اسـت از تجربه هيجانها و و افكار

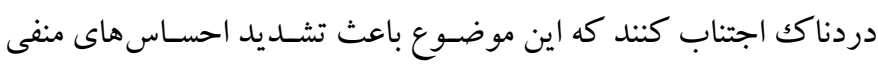
در طولانى مدت مىشود ( آ⿱ ).

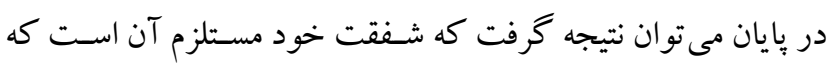

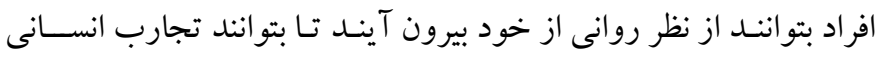

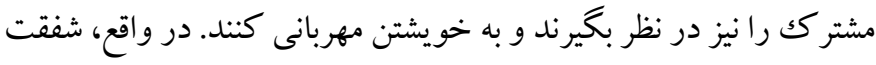

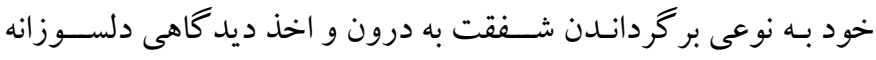

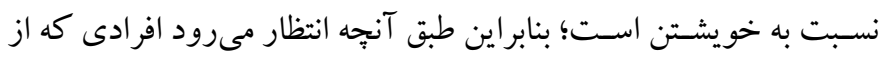

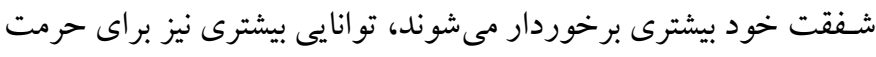

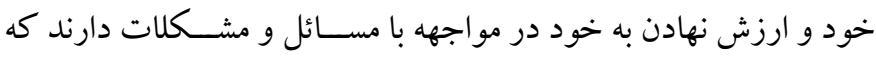

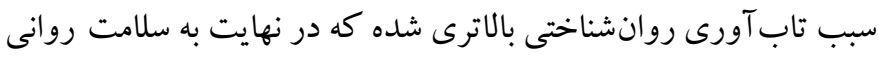

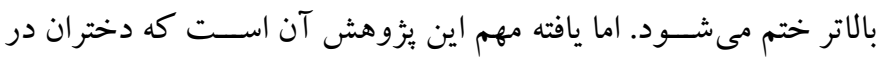

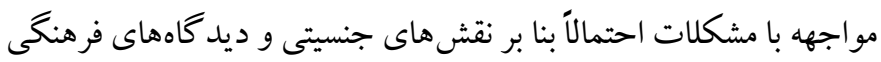

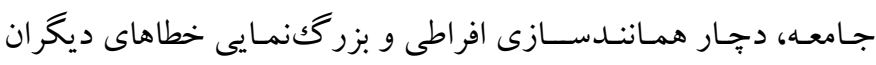
مىشـوند كه در نهايت سـبب كاهش همدلى و بخشـايش سـالم در آنها مىشـود. در نتيجه با توجه به اين نتايج بيشـنهاد مىشـود كه در مداخلات 
حامى مالى: اين مطالعه بدون حامى مالى انجام شده است نقش هر يكك از نويسـند كان: نو يسـنده نخسـت اين مقاله به عنوان تهيه كننده بسـته

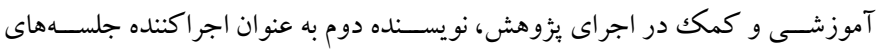

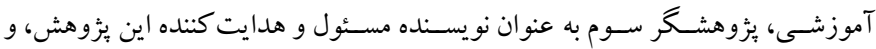

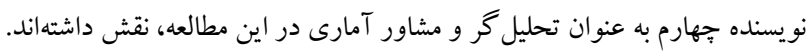

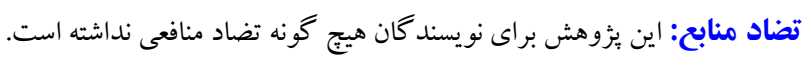

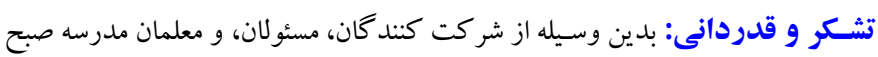

رويش تشكر و قدرانى مىشود.
كـاربردى تعـامـلمحور در اين مراكز بـهـ منظور ارائسه راهكـارهـايى براى افزايش حرمت خود و همدلى و به تبع آن ســلامت روانى كود كان مفيد

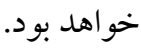

ملاحظات اخلاقى ييرورى از اصـول اخلاق يخووهش: اين مطالعه به صورت مستقل انجام شده است. مجوز اجراى اين يُزوهش بر روى افراد نمونه از سوى مؤسسه صبح رويش شهر تهران با بان

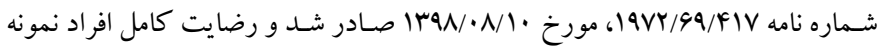
جلب شده است. 


\section{References}

1. Blustein D. L., Olle C., Connors-Kellgren A., \&Diamonti A. J. Decent work: A psychological Perspective. Frontiers in Psychology. 2016; 7(5): 110. Doi: 10.3389/fpsyg.2016.00407 [Link]

2. Kamruzzaman M. Child victimization at working places in Bangladesh. American Journal Applied Psychology. 2015; 4(6):146-159. Doi:10.1 1648/j. a j ap.20150406.13 [Link]

3. Khakshour A., AjilianAbbasi M., Sayedi S. J., Saeidi M., \&Khodaee G. H. Child labor facts in the worldwide: A review article. International Journal of Pediatrics. 2015; 3(12): 467- 473. Doi:10.22 038 / I JP.2015.3946 [Link]

4. ThabetA., Matar S., Carpintero A., BankartJ., $\&$ Vostanis P. Mental health problems among labour children in the Gaza Strip. Child: Care, Health and Development. 2011; 37(1): 89-95. Doi: 10.1111/ j. 1365-2214.2010.01122.x. [Link]

5. Kazemi Aliabad Z, Khosrojavid M. Effect of Role Play Training on Self-esteem and Adjustment of Students. J Child Ment Health. 2018; 5 (1):105-116. [Persian]. [Link]

6. Kiviruusu O, Berg N, Huurre T, Aro H, Marttunen M, Haukkala A. Interpersonal Conflicts and Development of Self-Esteem from Adolescence to Mid-Adulthood. A 26-Year Follow-Up. PLoS One. 2016, 11(10); 1-29. Doi: 10.1371/journal.pone.0164942. [Link]

7. Saadati N, Rostami M, Darbani S A. Comparing the effectiveness of Acceptance and Commitment Therapy (ACT) and Compassion Focused Therapy (CFT) on improving Self-esteem and post-divorce adaptation in women. ijfp. 2017; 3 (2):45-58. [Persian]. [Link]

8. Saeedi Z, Ghorbani N, Sarafraz M.R, Sharifian M.H. The effect of inducing self-compassion and selfesteem on the level of the experience of shame and guilt. Contemporary Psychology, 2013; 8(1): 91-102. [Link]

9. Andersen B, Rasmussen P.H. Transdiagnostic group therapy for people with self- critic and low selfesteem, based on compassion focused therapy principles. Journal of Compassionate Health Care. 2017; 4(14): 1-11. Doi: org/10.1186/s40639-0170043-1 [Link]

10. Pasyar S, Mousavi S V, Rezaei S. Prediction of the Resiliency of Labor Children based on Coping Strategies with Stress and Attachment Styles. J Child Ment Health. 2019; 5 (4):1-12 [Persian]. [Link]
11. Yaghoubi S, Akrami N. Role of Self-Compassion in Prediction of Forgiveness and Empathy in Young Adults. Journal of Positive Psychology Research. 2016; 3(1):35-48. [Persian] [Link]

12. Birnie K., Speca M. \&Carlson L. E. Exploring selfcompassion and empathy in the context of Mindfulness-based stress reduction (MBSR). Stress and Health. 2010; 26(5): 359-371. Doi: 10.1002/ smi.1305 [Link]

13. Maltby J., Macaskill A. \& Gillett R. The Cognitive Nature of Forgiveness: Using Cognitive Strategies of Primary Appraisal and Coping to Describe the Process of Forgiving. Journal of Clinical Psychology. 2007; 63(6): 555-566. Doi: 10.1002/jclp.20367 [Link]

14. Hassanzadgan M. saeidirezvani N. The Effect of Applying the Model of Story Telling by the Supportive Parent's Training on the Labor Children's Aggressive Behavior: the Model of Transactional Analysis. Two Quarterly Contemporary Sociological Research. 2015; 4(7): 79-98. [Persian]. [Link]

15. Siadat M., Jadidi M. The effect of social skills training on self-esteem and identity of working children. Educational Psychology. 2014; 3 (7): 83101. [Persian]. [Link]

16. Abbastabar M., Hashemi H. \&Abdollahi M. ProblemSolving and working memory in children. Quarterly of Clinical Psychology Studies. 2018; 8(29): 21-43. [Persian]. [Link]

17. Khaniki E., Motamedi A. The effect of solution-based group counseling on self-efficacy and social support of working children. Child's Mental Health. 2016; 4 (1): 110-118. [Persian]. [Link]

18. Riahinia M., Makarem M., Farajipour A., Haseli N. The Effect of Group Book Therapy onEnhancing Selfesteem in Working Children. Counseling Research. 2014; 5(4):111-125. [Persian]. [Link]

19. Cole-King A., \& Gilbert P. Compassionate care: the theory and the reality. Journal of Holistic Healthcare. 2011; 3(8), 94-110. [Link]

20. Crawford P., Brown B., Kvangarsnes M., \& Gilbert $\mathrm{P}$. The design of compassionate care. Journal of Clinical Nursing. 2014; 23(23-24): 3589-3599. Doi: 10.1111/jocn.12632 [Link]

21. Neff K. D., Pommier E. The relationship between self-compassion and other focused concern among college undergraduates, community adults, and practicing meditators. Self and Identity. 2013; 12(2): 160-176. Doi: org/10.1080/15298868.2011.649546 [Link]

22. Craig C., Hiskey S., \& Spector A. Compassion focused therapy: a systematic review of its 
effectiveness and acceptability in clinical populations. Journal of Expert Review of Neurotherapeutics. 2020; 20(4): 385-400. Doi: 10.1080/14737175. 2020.1 746184 [Link]

23. Lincoln T.M., Hohenhaus F., \& Hartmann M. Can Paranoid Thoughts be Reduced by Targeting Negative Emotions and Self-Esteem? An Experimental Investigation of a Brief Compassion-Focused Intervention. Cognitive Therapy and Research. 2013; 37(2): 390-402. Doi: 10.1007/s10608-012-9470-7 [Link]

24. Heriot-Maitland C., Vidal J.B., Ball S., \& Irons C. A compassionate-focused therapy group approach for acute inpatients: Feasibility, initial pilot outcome data, and recommendations. British Journal of Clinical Psychology. 2014; 53(1): 78-94. Doi: 10. 1111/bj c.1 2040 [Link]

25. Zarei F. The Effectiveness of Compassion-Focused Therapy in the Treatment of Depression and Blood Glucose Control in Patients with Type 2 Diabetes. [Thesis for Master of Art]. [Kurdistan, Iran]: Faculty of social Sciences, Kurdistan University; 2013, pp (abstract). [Persian]. [Link]

26. Gilbert, P. Compassion-focused therapy: Distinctive features (CBT distinctive features). First edition. New york: Routledge. 2010; 93-99. [Link]

27. Eslamian A., Moradi A., \&Salehi A. Effectiveness of Compassion Focused Group Therapy on Sleep Quality, Rumination and Resilience of Women in Isfahan City Suffering from Depression in Summer 2018. International Journal of Medical Investigation. 2019; 8(4): 41-50. [Link]

28. Neff K. D., \& McGehee P. Self-compassion and psychological resilience among adolescents and young adults. Self and Identity, 2010, 9(3), 225-240. Doi:10.1080/15298860902979307 [Link]

29. Skoda A.M. The relation between self-compassion, depression, and forgiveness of others [Thesis of Master of Art]. [Ohio, USA]: The College of Arts and Sciences, University of Dayton; 2011; pp 21-24. [Link]

30. Finlay-Jones A.L., Rees C.S., \&SKane R.T. SelfCompassion, Emotion Regulation and Stress among Australian Psychologists: Testing an Emotion
Regulation Model of Self-Compassion Using Structural Equation Modeling. PLOS ONE. 2015; 10(7): 1-19. Doi:10.1371/journal.pone.0133481 [Link]

31. Fredrickson B.L. The broaden-and-build theory of positive emotions. Philosophical Transactions of the Royal Society B: Biological Sciences. 2004; 359(1449): 1367-1377. [Link]

32. Exline J. J., Baumeister R.F., Zell A.L., Kraft A.J. \& Witvliet C.V.O. Not so innocent: Does seeing ones own capability for wrongdoing predicts forgiveness? Journal of Personality and Social Psychology. 2008; 94(3): 495-515. Doi: 10.1037/ 0022-3514.94.3.495 [Link]

33. Neff K.D., Beretvas S.N. The role of self-compassion in romantic relationships. Self and Identity. 2013; 12(1): 78-98. Doi: 10.1080/15298868.2011.639548 [Link]

34. Coppersmith, S. (1967), The Antecedents of Selfeskem.san rancisco: w.h. Freeman \& Co. [Link]

35. Moshkani M, Nuori E, Lotfi M, Ebadinya G. Effect of Phonological Awareness on Improving Reading and Self-esteem of Students with Dyslexia. J Child Ment Health. 2017; 4 (3):107-118. [Persian]. [Link]

36. Rye, M. S., Loiacono, D. M., Folck, C. D., Olszewski, B. T., Heim, T. A., \& Madia, B. P. Evaluation of the psychometric properties of two forgiveness scales. Current Psychology.2001; 20(3): 260-277. Doi: 10.1007/s12144-001-1011-6 [Link]

37. Zandipour T., Yadegari H. The Relationship between Forgiveness and Life Satisfaction in Non-Indigenous Married Student Students of Tehran Universities. Socio-psychological Studies of Women. 2006; 5 (3): 109-122. [Persian]. [Link]

38. Davis M. H. Measuring individual differences in empathy: Evidence for a multidimensional approach. Journal of Personality and Social Psychology. 1983; 44(1):113-126. doi.org/10.1037/ 0022-3514.44.1.113 [Link]

39. Abolghasemi A., Taherifard M., kiyamarsi A. Comparison of Emotional Memory, Decision-Making and Interpersonal Reactivity in Student with Conduct Disorder and Normal.Psychological Studies. 2017; 13(2): 43-58. [Persian] [Link] 